\title{
Designing and Validating the Moral Education Model in the Elementary School of the Educational System of the Islamic Republic of Iran
}

\author{
Zahra Kooshi ${ }^{1}$, Nematollah Mosapour ${ }^{2}$, Mohammad Armand ${ }^{3}$, Ali Mohebi ${ }^{4}$
}

- Objective: The present study was to present a model of moral education in elementary school.

- Methodology: The mixed research method was done through a qualitative-quantitative design. The statistical population of the qualitative research consisted of articles, theses and dissertation, documents, and books from 2012 to 2020 and the statistical population of the quantitative research included the teachers of the senior elementary school in Kerman. The study sample was based on purposive sampling method in qualitative research and simple random sampling method in quantitative research. The data collection tool in the qualitative research was taking notes of articles, theses and dissertations, and books, and in the quantitative research, it was questionnaires. For analysis of the data in the qualitative research and in the quantitative research, the content analysis method and the second-order confirmatory factor analysis were respectively used.

- Findings: The findings showed that 35 basic themes, 11 organizing themes, and 3 comprehensive themes were identified in three areas: cognition, belief and moral behavior. Then a questionnaire was designed to validate the model with 35 items. The reliability of the questionnaire was calculated through Cronbach's alpha (0.95) and validity (face and content) was calculated according to the opinions of experts of education and through the counting sigma method of 0.85 . Confirmatory factor analysis method was used to validate the research model. In the quantitative research, the findings showed that all themes with high factor load were confirmed; this indicated the high validity of the model.

- Conclusion: According to the findings of this study and focusing on the model of moral education, it is possible to help to improve the level of cognition, belief and moral behavior of the elementary school students.

Keywords: moral education, model of moral education, elementary schools.

Citation: Kooshi, Z., \& Mosapour, N., \& Armand, M., \& Mohebi, A. (2020). Designing and Validating the Moral Education Model in the Elementary School of the Educational System of the Islamic Republic Of Iran. Applied Issues in Islamic Education, 5(3): 127-154.

1. A Ph.D. Student in Curriculum Planning, Islamic Azad University, Science and Research Branch, Tehran, Iran.

E-mail: Zahra kooshi@yahoo.com. (iD) 0000-0003-3925-3171

2. Corresponding Author: Associate Professor in curriculum planning, Farhangian University, Tehran, Iran. E-mail: n_mosapour@uk.ac.ir. (iD 0000-0002-0985-0736

3. Associate Professor in Curriculum Planning, the Institute for Humanities Research and Development, SAMT, Tehran, Iran.

E-mail: Armand@samt.ac.ir. (ID) 0000-0003-2136-288x

4. Associate Professor in Curriculum Planning, Organization for Educational Research and Planning, Tehran, Iran.

E-mail: pajohesh.university@police.ir. (iD) 0000-0002-1260-9265 


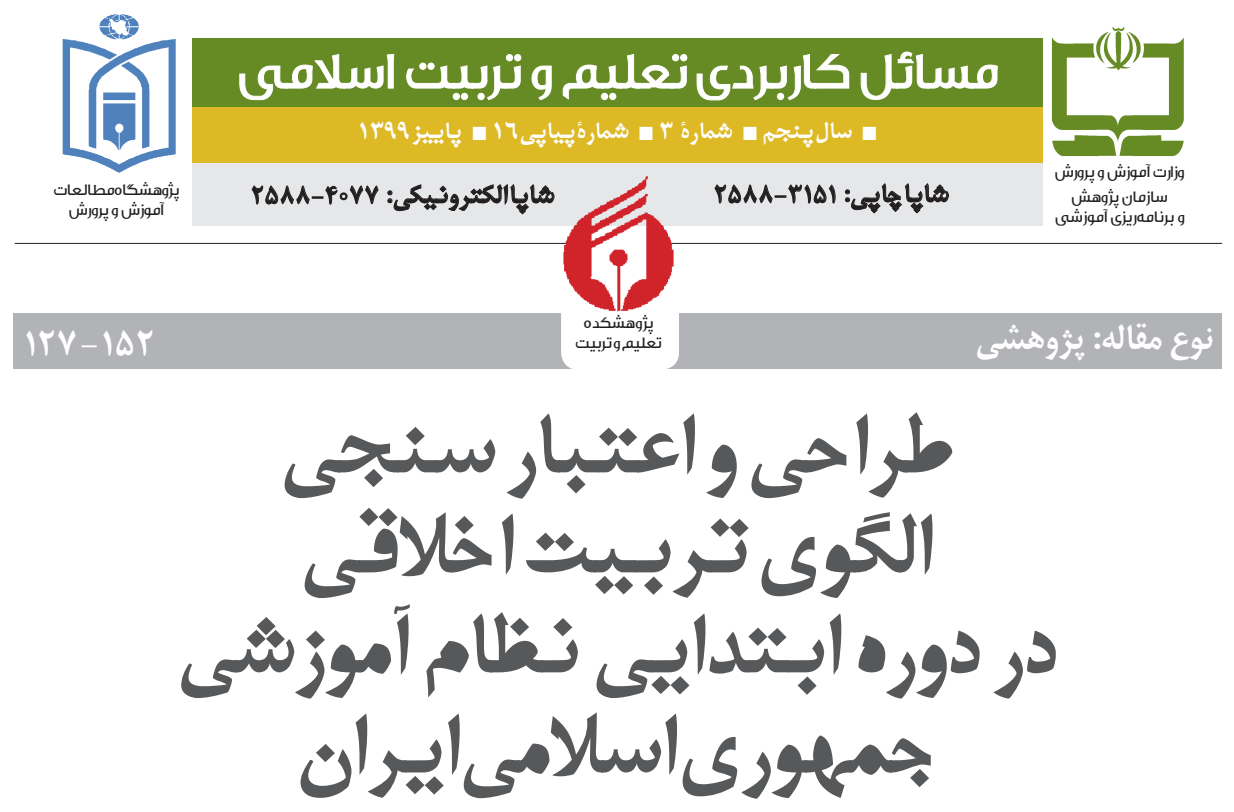

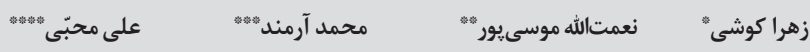

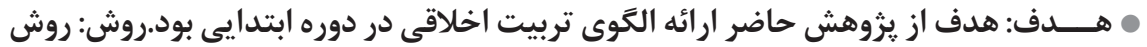

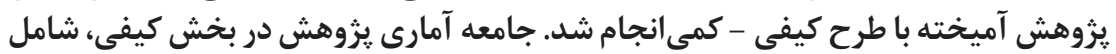

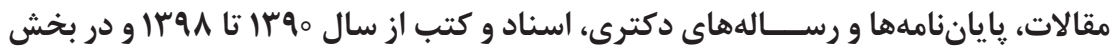

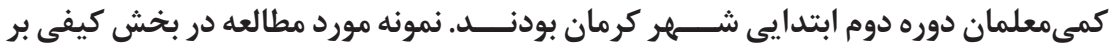

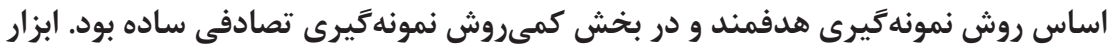

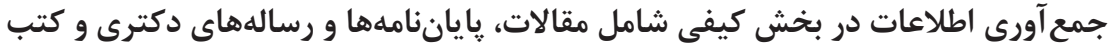

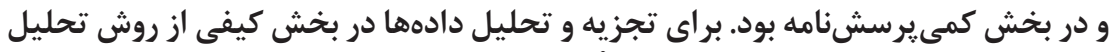

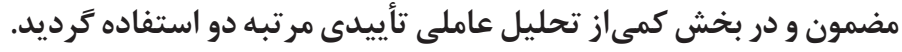

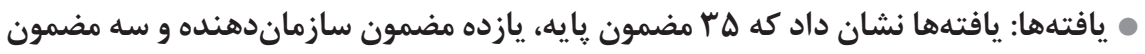

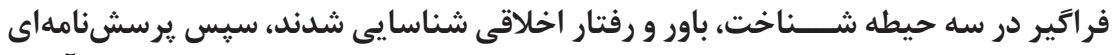

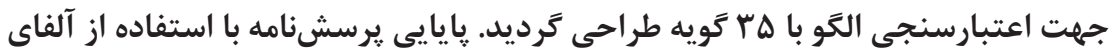

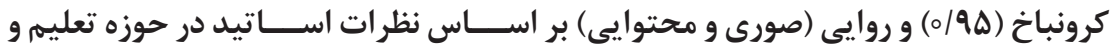

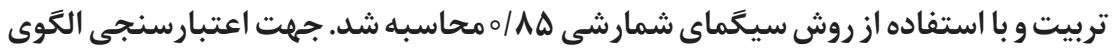
H

$$
\text { ם تاريخ يذيرش: }
$$

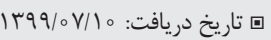

* دانشجوى دكتراى تخصصى رشته برنامهريزى درسى، واحد علوم و تحقيقات، دانشًاه آزاد اسلامى، تهران، ايران. Email: Zahra_kaveshi@yahoo.com iD 0000-0003-3925-3171

Email: n_mosapour@uk.ac.ir (D) 0000-0002-0985-0736

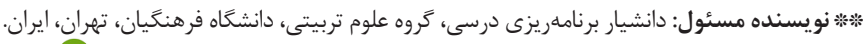

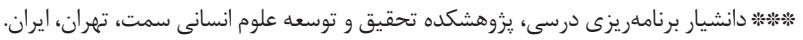
Email: Armand@samt.ac.ir (ID) 0000-0003-2136-288x

Email: pajohesh.university@police.ir (iD) 0000-0002-1260-9265

$$
\text { . }
$$

$$
\text { " ا / مقاله مستخرج از رساله دكتراى تخصصى رشته برنامهريزى درسى دانشكاه آزاد /سلامى، واحد علوم و تحقيقات تهران است. }
$$




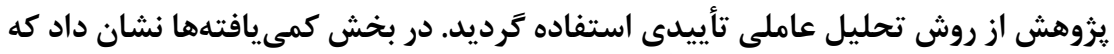

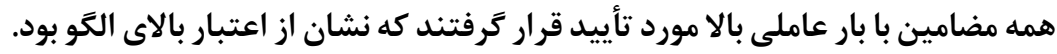

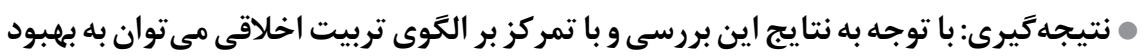

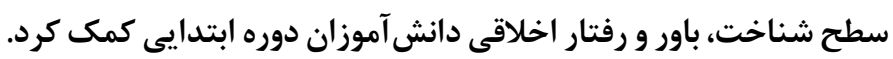

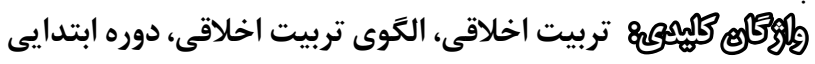

مقدمه

تأكيد بر تعليمى و تربيت نشــان مىدهد هيج نظام تربيتى رانمى توان يافت كه براى تربيت انســانها كوشش كند ولى جهت كيرى مشــصى نداشته باشد. تعليمى و تربيت،

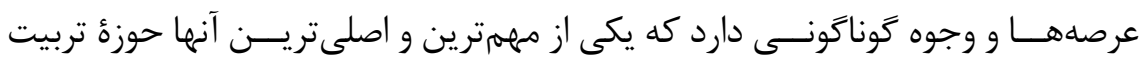
اخلاقى ' است. تربيت اخلاقى بخشى از برنامه تربيتى انسان مىباشد كه ضامن شكوفايى استعدادهاى علمىو عملى اخلاقى است و يرورش شخصيتى آراسته به فضايل اخلاقى را امكانيذير مىسازد. انسانها بدون اخلاق و تربيت اخلاقى توانايى زندكى كردن در كنار يكديگر را ندارند. حتى جوامع ييشرفته هم بدون اخلاق و تربيت اخلاقى ادامه زندگى را مشكل مى مانند. امروزه تربيــت اخلاقى در همه كشــورها بهعنوان يكى از الزامــات تعليمم و تربيت

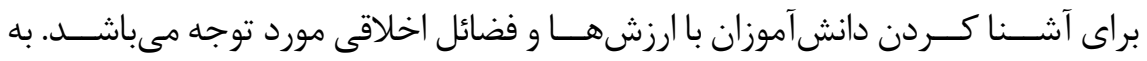

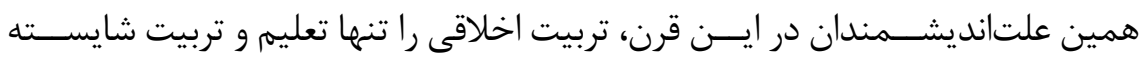

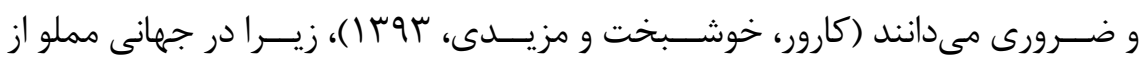

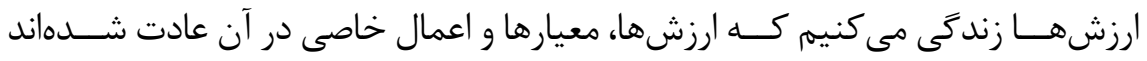
.(Johansson \& Brownlee, Charlotte- Moore, Boulton- Lewise, Walker, Ailwood, 2011) ارزش ها مفاهيمى اعتبارى هستند كه انســانها در مقام عمل به آنها ملتزم و پايبند مىباشند و بر اساس آنها اقدام و رفتار مى كنند. آموزش ارزشها در يـى آن آن است تا افراد جامعه، ترجيحات ارزشــى و جهت گيرى خود را به گونهاى شـــل دهل دهند كه راهنماى

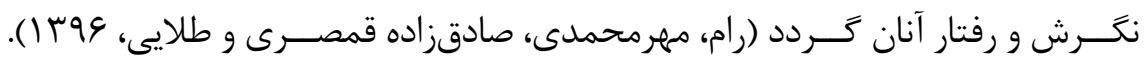


بنابراين، تربيت اخلاقى از مهمهترين و مشكلترين كارهاست و انجام اين كار از هدفهاى مهرم و والاى جوامع بشرى مىباشد (Halsted \& Taylor, 2000). امروزه از اخلاق بهعنوان الكَى رفتارى ياد مى گردد، اخلاق مســئوليتيذيرى فرد در رفتار ارتباطى است كه به رعايت حقوق ديخران معطوف مى گردد (Bucciarelli \& Monica, Laired, Johnson, 2008). اين رفتار ارتباطى اعم از رفتار درون شخصى (من با خودم)، رفتار ارتباطى بين شخصى (افراد انسان با يكديخر)، رفتار ارتباط برون شخصى (با خدا، با محيط زيست و با حيوانات) و رفتار ارتباطى سازمانى با محيط درونى و بيرونى خود است (Halsted \& Taylor, 2000). بنابراين، تربيت اخلاقيات در جامعه از مهممترين آرمانهاى بشرى مىباشد و و آموزش

رسمى فرصتى مناسب براى بستر اخلاقيات در جامعه است (Bryan \& Burstow, 2018). تربيت اخلاقـى و ״رورش ويزگى هاى اخلاقى (مانند انصاف، احترام، صداقت، امانتدارى، وفاى به عهد، مســـئوليت يذيرى و وياى بندى بهدســتورات اخلاقـى در دانش آموزان از

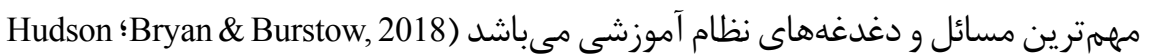
,Giordmaina \& Zammit ؛Jenifer, 2020 ؛ kristjansson, 2016 ؛ Diaz Pearson, 2018

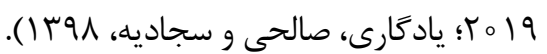

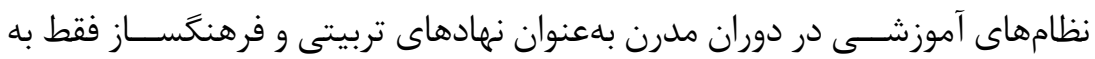
انتقال بُعد دانشــى به دانش آموزان محدود نبوده و كاركـــــ هنجارين، ارزش بنيادين و

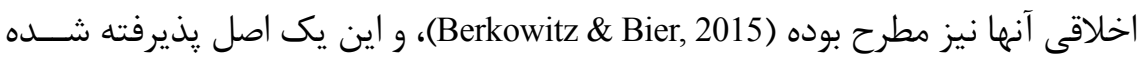
است كه كاركرد مدرسه فقط به اين عامل خلاصه نمىشود كه افرادى هوشمند يرورش دهند كه در دنياى رقابتى امروز بتوانند از رقباى خود ســبقت گيرند، بلكه در كنار اين

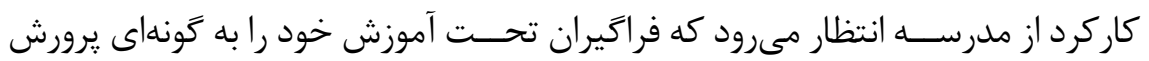
دهند كه توانايیى آن را داشــته باشند كه درست را از نادرست اخلاقى تشخيص دهند. بر همين اساس تربيت اخلاقى هميشه يكى از اهداف اصلى و يايدار در نظامهاى آموزشى در ســـح دنيا بوده است (Sandeep, 2015؛Bischoff, 2016)، و آموزش اخلاقيات و ارزشها بهعنوان يك مسئوليت مهرم و سنگين بر دوش نظامهاى آموزشى و تربيتى جهان احساس مىشود (kristjansson, 2016)، و مدارس نمى توانند و نبايد در برابر موضع اخلاق ساكت باشند، زيرا تربيت اخلاقى بر بحران هويت دانشآموزان مؤثر است. در حقيقت نوجوانان در شــكل دادن به هويت خود از قابليت انتخاب برخوردارند و مى توانند تجارب مثبت و 
هويت موفق را از طريق رفتار مســـئولانه در زندگى و مواجهه با مشكلات بهدست آورند (وحيدى و شاه جوان، و (1)). يكى از مسائل مههم در تربيت اخلاقى كه بايد مورد توجه جدى قرار زيرد رويكردهاى تربيت اخلاقى اســت. بررسى ديدكاههاى انديشمندان مسلمان نشان مىدهد كه تربيت اخلاقــى رويكردى فردى اســت كه به عوامل ارتقاء اخلاقى جـــون ايمان، زهد، و توكل توجه مى شـــود (عباسى، دانشىفرد و ييكانى، وجس ا؛ قاسمى، شرفى، سجادى و ايروانى،

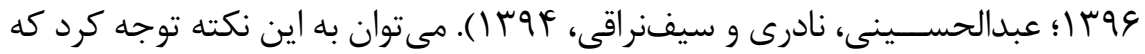
اخلاقى بودن در بســـتر زندگى اجتماعى بروز مىيابد. بروز ويزگَى هاى اخلاقى در انسان مســتلزم حضور او در اجتماع اســت. بدون حضور در بســـتر زندكى اجتماعى نمى توان به اين ويزگى ها دســت يافت. بنابر اين، اخلاقى بودن وابســــه است به اجتماعى زيستن

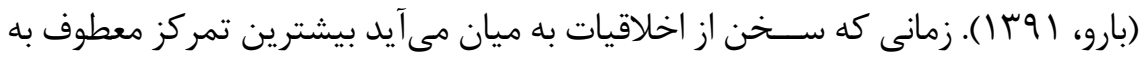
روابط و تعاملات انسانى است. رفتار اخلاقى فرد در مواجهه با ديخران محقق مى گردد و در انسان تثبيت مىشود. توانايىهاى عملى انسان در برخورد با ديخران، مقولهاى در زمينه تربيت اخلاقى است كه نبايد مورد غفلت قرار گيرد، ولى متأسفانه تقويت جنبههاى بيرونى اخلاق كه در تعامل با ديخران رخ مىدهد مورد غفلت قرار گرفته است (قاسمى، وه؟ ا). اتــــر در فراينـــد تربيت اخلاقى، ييوند ميان اخلاق و بســـتر اجتماعى مــورد توجه قرار

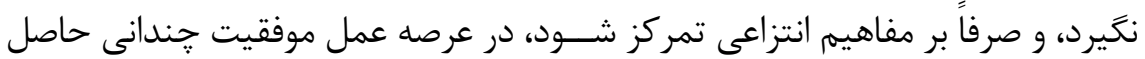
نخواهد شــد. آموزشويرورش بايد به دانشآموزان كمك كنـــد تا ارزشهاى اخلاقى را بهمنظور برابرى و عدالت اجتماعى كسب نمايند. شواهد و قرائن حاكى از آن است كه در مدارس مهارتهاى توانايى مسئوليتيذيرى، توانايى درك متقابل، همكارى و مشاركت، احترام به ســنن و فرهنگَها، دَرخواهى، آَاهى از محيط زيست، صلح و حقوق بشر و

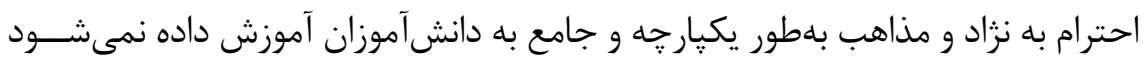
(قاسمى، عوبـا؛Butcher, 2017). خلأهاى بسيارى در برنامههاى تربيت اخلاقى در سراسر

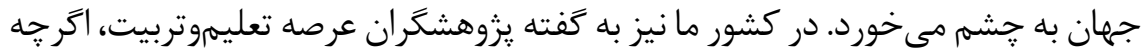
تلاشهاى فراوانى در ترويج ارزشهاى اخلاقى صورت گرفته، اما اهداف مورد نظر محقق نشده است. رفتار نسل جوان ما نشان مى دهند كه اين جامعه دجار افول حريمهاى اخلاقى

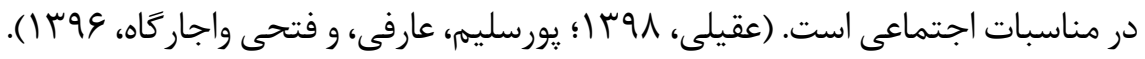


يافتههاى برخى از يزوهشها به ييامدهاى خلأو كمرنت شــدن مناســـات اجتماعى و ديخرخواهى در تربيت اخلاقى اشاره نمودهاند (قاسمى، وجس|). بنابراين ضرورت توجه به عوامل ارتقاء اخلاقى احساس مى گردد. از ميــان مقاطع تحصيلى، اين يزوهش در مقطع تحصيلى دوره دوم ابتدايى (جهارم، ينجمى و ششــم) انجام شد. تربيت اخلاقى در دوره ابتدايى با ابهامات و جالش هاى نظرى مواجهه اســت (عقيلى، هوس (). دوره ابتدايى با تحولات و شـــرايط جديدى همراه است كه بر شخصيت كودى و ساز ₹ارىهاى اجتماعى او تأثير مى حذارد. شخصيت كودك در

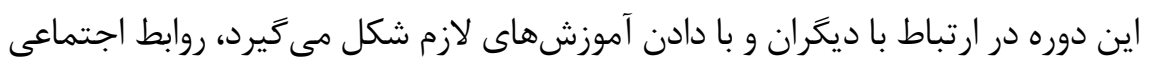
توســعه يافته و ادراكش از مسائل اجتماعى و فرهنگى عميقتر مى گر دد (سيف، كديور،

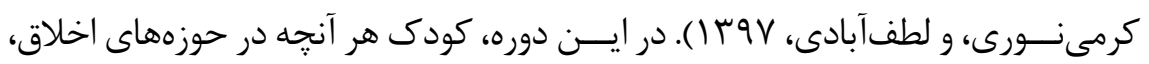
باورهــاى دينى، فرهنخَـى و اجتماعى بياموزد، در بقيه دوران زندگى با او همراه اسـتـ (اســــرايكر و وارنر، سوسا). با توجه به اين كــهـ تاكنون الخوى تربيت اخلاقى براى دوره ابتدايى طراحى و تدوين نشــده اســت. از اين رو براى ير كردن اين خلأ يزوهشى و كم رنت كردن اين خصلت منفى در تربيت اخلاقى و برداشــتن گام نخست در طراحى آن، على الخصوص در مقطع ابتدايى نظام آموزشــى اين :يزوهش تلاش كرد تا اصول حاكم بر الگوى تربيت اخلاقى را بر اساس تحليل محتوا و منابع شناسايى نمايد. مرور يزوهشهاى ييشين نشان مى دهد كه تربيت اخلاقى داراى ييشينه قابل توجهى اســت. مرورى انتقادى تحقيقات انجام شده درباره تربيت اخلاقى حاكى از آن است كه از رويكردهاى فردى اســتفاده شده اسـت و توجهى به رويكردهاى اجتماعى و يرورش شهروند جهانى نشده است (يورسليم و ديخران، و9 ا ). برخى از اين تحقيقات در ادامه

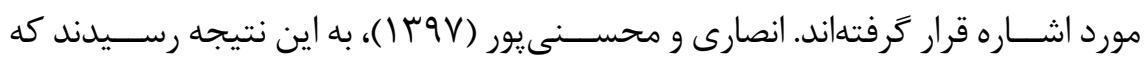
فرصتهاى تربيت اخلاقى در سه حيطه شناختى، عاطفى و رفتارى بوده است. در جنبه شـــناختى تقويت قدرت تحليل و ارزيابى مفاهيم ارزشها و فضايل اخلاقى، به كار كيرى شـــيوههاى آموزشــى اثربخش، در جنبه عاطفى تقويت تعامــلات عاطفى دانشى آموزان بـــا معلمان و والدين و در جنبـــهـ رفتارى تقويت تمايل به كســـب ارزشهاى اخلاقى و بهبود شـــيوههاى تربيتى مديران، دبيران، مربيان يرورشى و والدين را مدنظر قرار دادند. عباسى (צوس ()، در يزوهش خود تربيت اخلاقى را بر اساس ديدگًاه قرآن بررسى نموده 
و دريافت كه تربيت اخلاقى در دو بُعد باور و رفتار دستهبندى مىشود و همانندشناسى و بينش نســبت به خود در بُعد باور قرار دارد. شكارى، رحيمى و غربا (سوس|)، با نظر به اهميت تربيت اخلاقى به دنبال آسيبشناسى تربيت اخلاقى از منظر برنامه درسى ينهان بودند، و به مؤلفههاى شجاعت، احترام، صداقت، صبر، وفادارى، امانتدارى، حسن خلق، توكل و وجدان در دو بعد فردى و اجتماعى دست يافتند. نتايج يزوهش ظاهر (هوبا)، نشان داد كه آســيبهاي تربيت اخلاقى در ابعاد شناختى، عاطفى و احساسى، و عملى مىباشـــند. (Jones \& Warnaar, Bench, Stroup, 2014)، در يزوهــش خود دريافتند كه دانشآموزان ســـح بالايى از شاخصهاى فردى و اجتماعى تأثير گذار بر هويت اخلاقى، رفتار و عمل را دارا هستند. از اين رو معلمان از طريق روشهاو راهبردهاى نوين تدريس و يادَيرى مشــاركتى مى توانند هويت اخلاقى و مشاركت اجتماعى را در دانشآموزان ار تقاء دهند.

آنجه ضرورت انجام اين يُوهش را دو جندان مى كند، اين است كه عليرغم تلاشهاى فراوانى كه در زمينه تربيت اخلاقى صورت كرفته ولى خلأهاى بســيارى در برنامههاى

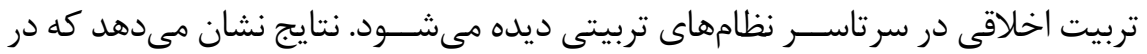
كشور ما اكثر يزوهشها در حوزه تربيت اخلاقى با تأكيد بر مبانى فلسفى و بدون توجه به ابعاد و مؤلفههاى تربيت اخلاقى با رويكرد اجتماعى تدوين شــدهاند (عقيلى، 19 |). همجنين در خصوص الكوهاى تربيت اخلاقى تعداد يزوهشهاى انجام شده بسيار محدود

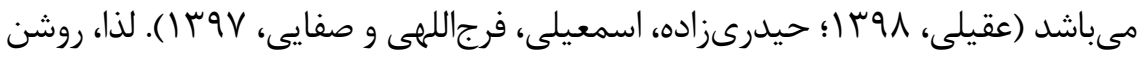
نمودن و تبيين دقيق اين الغو مىتواند در تربيت اخلاقى مؤثر باشـــــ از ســـويى ديخر، زمينههاى رشــدى مناسب كودكان دليل منطقى ديخر براى يرداختن به تربيت اخلاقى در دوران ابتدايى است. مطابق آموزههاى دينى هفت سال دوم كه تقريبأ مساوى با دوران ابتدايى در نظام تعليم و تربيت رســمى عمومى دواست با عنوان دوران تأديب و تربيت ياد شده است كه بايد والدين و دستاندر كاران تعليم و تربيت برنامههاى جدى در خصوص تربيت بهطور اعم و تربيت اخلاقى بهطور اخص داشــــه باشــــد. علاوه بر اين فيلسوفان معتقدند كه عادات رفتارى و خصلتهاى اخلاقى كه در دوران كودكى ايجاد شده باشند به مانند نقش و نكارى كه بر ســنَ حكى شده باشـــند به سختى تغيير خواهند كرد و

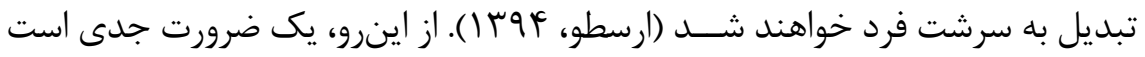




\section{$I T V-1 Q F$}

كه يروهشهاى گوناگونى در حوزه تربيت اخلاقى انجام گيرد. اكنون با توجه به اهميت اين موضوع در آموزش و يرورش، مســــله يزوهش حاضر اين است كه مؤلفههاى تربيت اخلاقى را در آموزش و يرورش شناسـايى كرده و الگوى تربيت اخلاقى در دوره ابتدايى آموزش و يرورش ايران ارائه دهد.

\section{روش :ثروهش}

روش يروهش از نوع آميخته و بهصورت كيفى و كمّى بود. در مرحله كيفى از تحليل

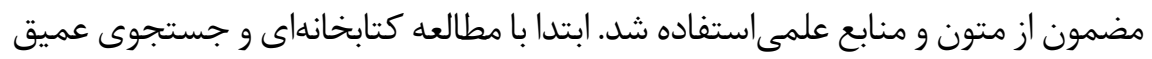
در منابع كتابخانهاى شــامل كتابها، مقالات معتبر، رسالههاى دكترى و ياياننامههاى كارشناسى ارشد و ســايتهاى علمىمعتبر و از طريق تحليل محتوا، مضامين استخراج شده مقولهبندى و دســتهبندى شـــدند. در بخش كمى از روش ييمايشى استفاده شد. بر اساس يافتههاى بخش اول يرسشنامهاى طراحى و اعتبارسنجى گرديد.

\section{جامعه آمارى، نمونه و روش نمونه}

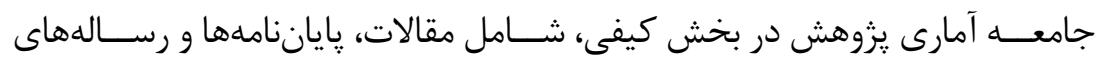
دكترى، اســناد و كتب مندرج در يايخاهها، وبســايتها، و كتابخانهها پيرامون اخلاق

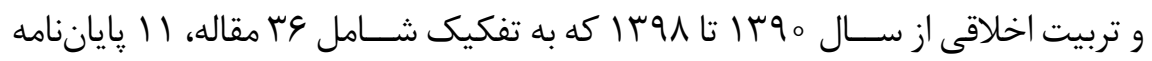

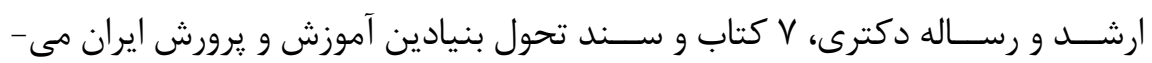

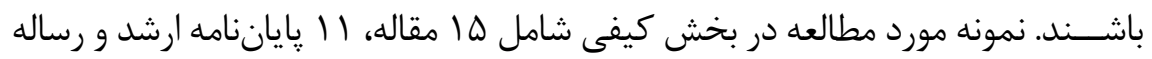
دكترى، ه كتاب و سند تحول بنيادين آموزش و يرورش كه بهصورت هدفمند بر اساس

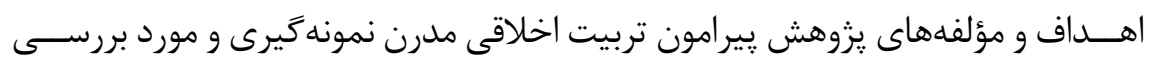
عميق قرار گرفتند. جامعه آمارى يزوهش در بخش كمى، شامل كليه معلمان دوره دوم

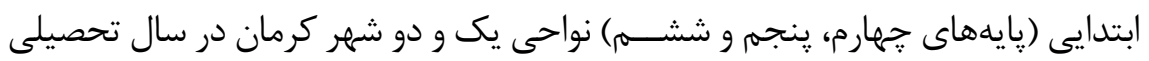

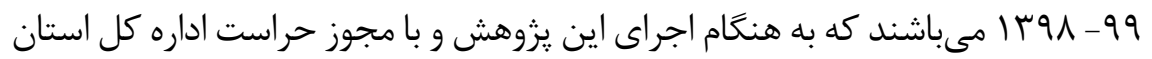
كرمان و از طريق كارشناسى دوره ابتدايى تعدادشان ه ه 11 نفر اعلام گرديد. حجم نمونه

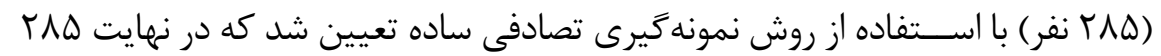




\section{ابزار جمع آورى اطلاعات}

ابزار جمع آورى اطلاعات در بخش كيفى شــامل ها مقاله، $1 \mid$ ياياننامه و رســاله

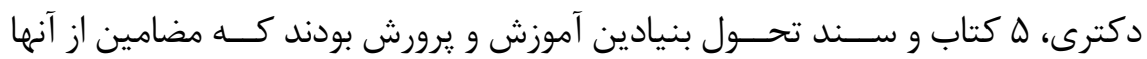

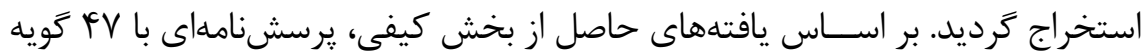

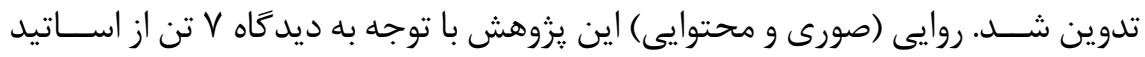

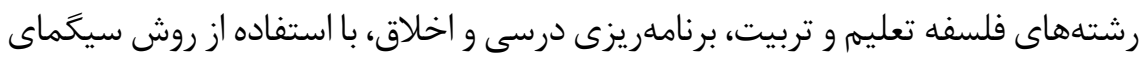

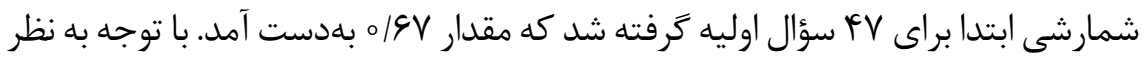

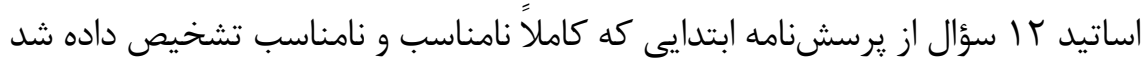

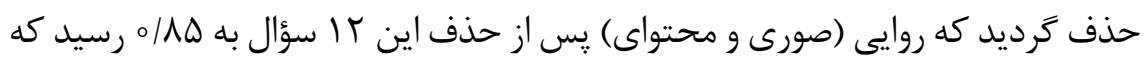

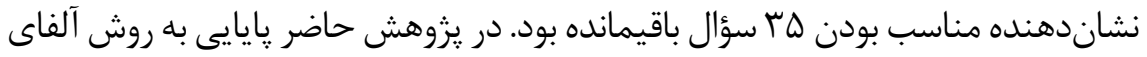

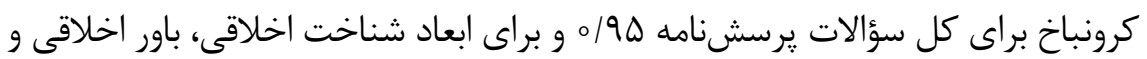

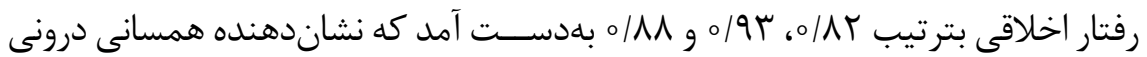

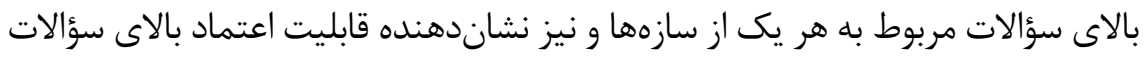

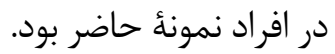

يافتهها يافتههاى بخش كيفى سؤال اول: كدام الكوى مفهومى إبراى تربيت اخلاقى در دوره ابتدايى مىتوان ارائه كرد؟ جدول ا. شاخصهاى تربيت اخلاقى

\begin{tabular}{|c|c|c|}
\hline نقل شده از & خرده مؤلفه & بُعد \\
\hline 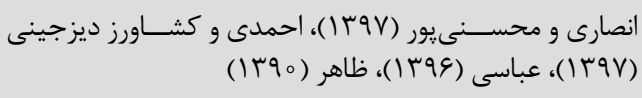 & آ آموزش توانمندى & \multirow{3}{*}{ 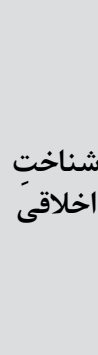 } \\
\hline 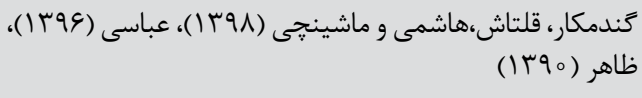 & 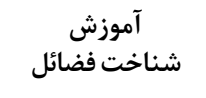 & \\
\hline 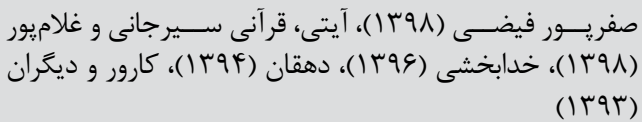 & 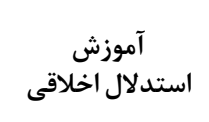 & \\
\hline
\end{tabular}




\section{$I T V-I Q F$}

جدول ا. (ادامه)

\begin{tabular}{|c|c|c|}
\hline نقل شده از & خر ده مؤلفه & بُعد \\
\hline 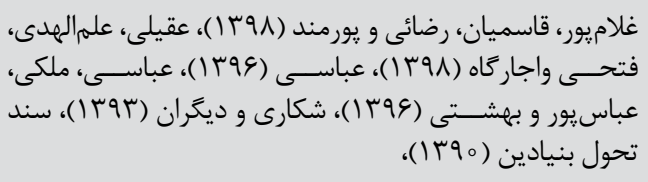 & 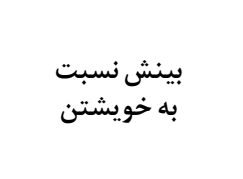 & \multirow{4}{*}{ باور اخلاقى } \\
\hline 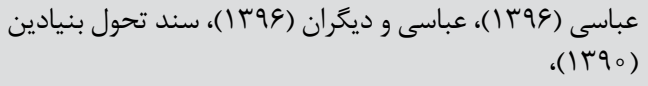 & 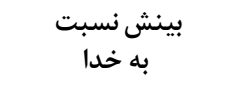 & \\
\hline 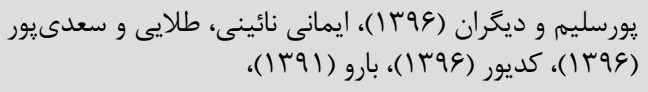 & سلامت محيط زندبت بـى & \\
\hline 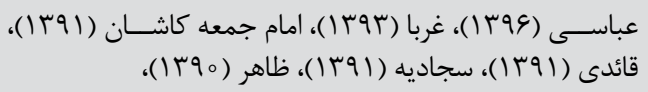 & إنغيزش جهاى اجتماعى تحيم & \\
\hline 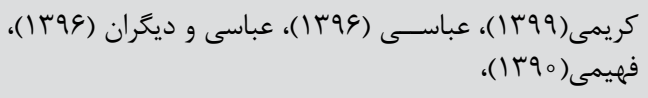 & مشاركت اجتماعى & \multirow{4}{*}{ رفتار اخلاقى } \\
\hline 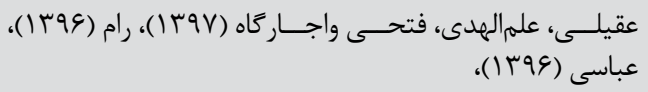 & آكاهى و هوشيارى & \\
\hline 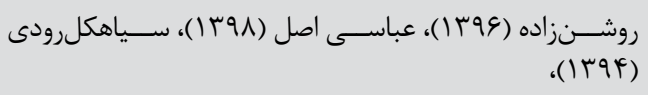 & تصميمَيرى اخلاقى & \\
\hline 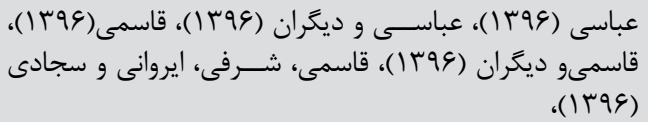 & انجام وظيفه و عمل & \\
\hline
\end{tabular}

در بخــش كيفى ابتدا مؤلفههاى تربيت اخلاقى با اســـفـاده از روش تحليل مضمون

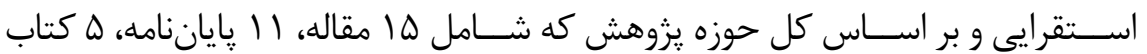

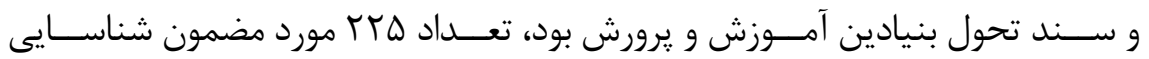
گَرديد. يس از حذف يا تلفيق مضامين مشـــابه و تكرارى، ســهـ دســــه مضمون فراتير: ا. شناخت اخلاقى شامل آموزش توانمندى در بازدارى و يرهيز، آموزش شناخت فضائل، و آموزش استدلال اخلاقى؛ r. باور اخلاقى شامل بينش نسبت به خويشتن، بينش نسبت به خدا، بينش نسبت به سلامت محيط زندگى، و انخيزش جهت تحكيم ييوندهاى اجتماعى و ". رفتار اخلاقى شامل مديريت صحيح، آكاهى و هوشيارى، تصميم خيرى اخلاقى، و انجام وظيفه و عمل به تكليف شناسايى شد و قالب مضامين نهايى شكل گرفت. 
يس از اينكه مضامين اســـتخراج شدند قالب مضامين نهايى تربيت اخلاقى ارائه شد و با توجه به اين قالب الكوى تربيت اخلاقى براى آموزش و يرورش ايران ارائه گرديد كه

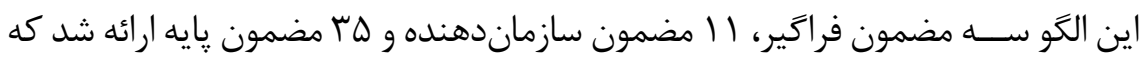

به شرح زير مىباشد. ا. شناخت اخلاقى شامل: مضامين ســازماندهنده آموزش توانمندى در بازئدارى و

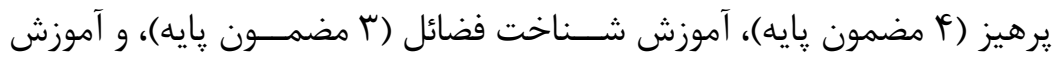

$$
\text { استدلال اخلاقى (س مضمون پايه). }
$$

r. باور اخلاقى شامل: مضامين سازمان دهنده بينش نسبت به خويشتن (أ مضمون يايه)،

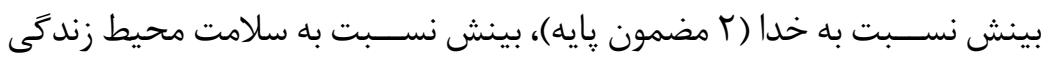

(r مضمون يايه)، انكيزش جهت تحكيم ييوندهاى اجتماعى (r مضمون يايه). r. رفتار اخلاقى شامل: مضامين سازماندهنده مشاركت اجتماعى (r مضمون یايه)،

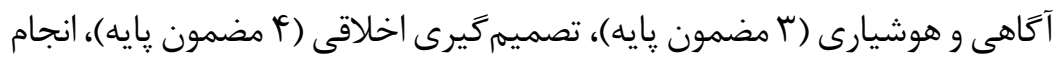

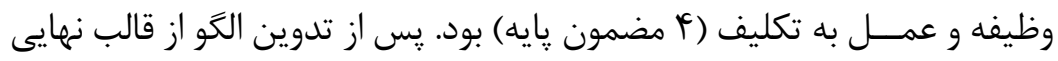
مضامين در ساخت ابزار اصلى يزوهش (يرسشنامه) استفاده شده است.

جدول r. مضامين فراتير، سازمان دهنده و يايه تربيت اخلاقى

\begin{tabular}{|c|c|c|}
\hline مضامين بايه & مضامين سازماندهنده & مضامين فراتير \\
\hline يرهيز از غرور & \multirow{4}{*}{ در بازدارى و يرهيز } & \multirow{10}{*}{$\begin{array}{l}: 3 \\
: 3 \\
: \bar{y} \\
: \sqrt[3]{3}\end{array}$} \\
\hline يرهيز از دروغ و دوكانكى در عمل & & \\
\hline يرهيز از خشونت & & \\
\hline يرهيز از انتقام جويى & & \\
\hline وفاى به عهد و ييمان & \multirow{3}{*}{ شناخت فضائل } & \\
\hline داشتن رفتار نيك همراه با مهربانى & & \\
\hline داشتن انصاف و عدل & & \\
\hline درك انجام كارهاى خوب & \multirow{3}{*}{ استدلال آموزشلاقى } & \\
\hline يرورش تفكر قانونى & & \\
\hline توجه به امر اختيار & & \\
\hline
\end{tabular}




\section{$I T V-I Q F$}

جدول r. (ادامه)

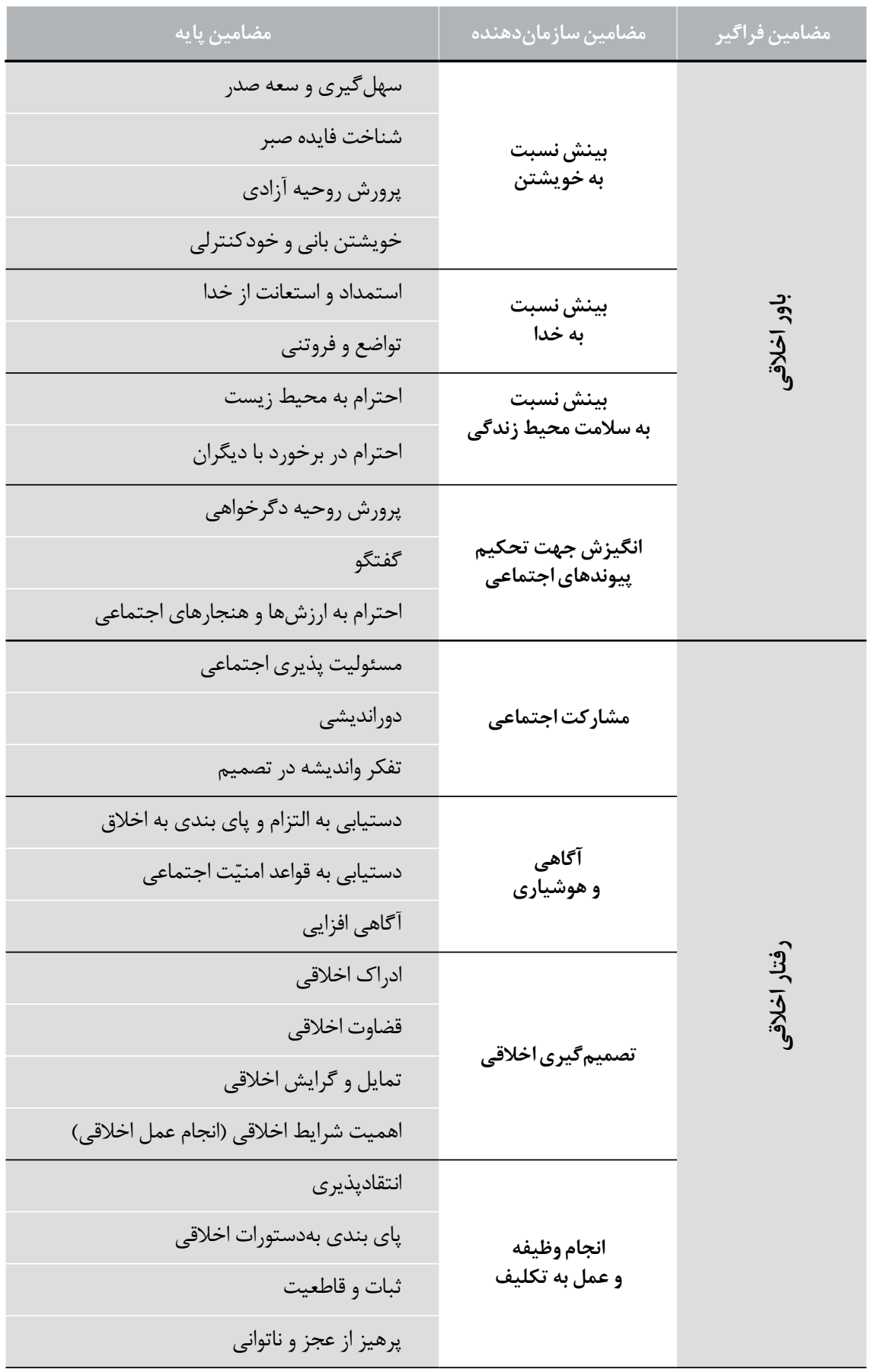




\section{يافنهای بخش كمى يثزوهش}

سؤال دوه: آيا الكَوى ارائه شده از اعتبار لازم برخوردار است؟

\section{يافتلهاى توصيفى}

بررسى مشخصات جمعيت شناختى ياســخ كويان بيانكر آن بود كه از نظر جنسيت

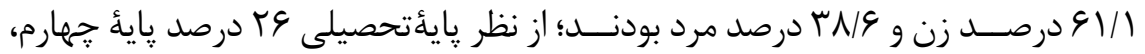

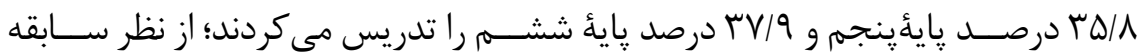

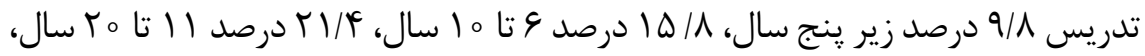

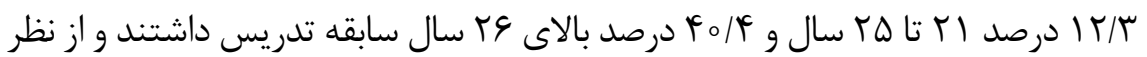

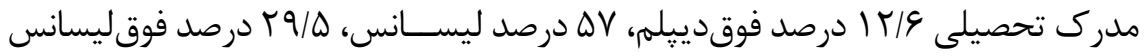

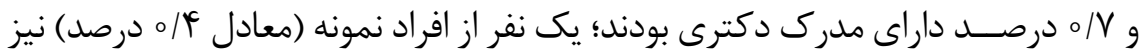

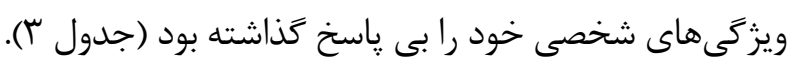

جدول r. توزيع فراوانى ياسخَويان به تفكيك برخى ويزَى هاى دموكر افيك

\begin{tabular}{|c|c|c|c|}
\hline ل درصد & فراوانى & سطح & متغير \\
\hline$\% 91 / 1$ & IVF & 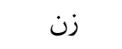 & \multirow{2}{*}{ جنس } \\
\hline$\%$ \%N/9 & 110 & مرد & \\
\hline$\%$ \% & $v^{F}$ & קֶايه جهارم & \multirow{3}{*}{ يايه تحصيلى } \\
\hline \% & 104 & يايه ينجمم & \\
\hline$\% r V / q$ & 101 & يايه ششم & \\
\hline$\%$ \%/^ & rA & كمتر از هـ & \multirow{5}{*}{ سابقهُ تدريس (به سال) } \\
\hline$\% \mid \Delta / \Lambda$ & $F \Delta$ & 1०ا & \\
\hline$\% r I / F$ & 9) & r & \\
\hline \% & ra & ا ا & \\
\hline$\% F \circ / F$ & 110 & ع ع به بالا & \\
\hline
\end{tabular}


جدول r. (ادامه)

\begin{tabular}{|c|c|c|c|}
\hline درصد & فراوانى & سطح & متغير \\
\hline$\% 1 T / 9$ & rG & فوق دييلم & \multirow{4}{*}{ مدرك تحصيلى } \\
\hline$\% \Delta V$ & IET & ليسانس & \\
\hline$\%$ \% / & $\Lambda F$ & فوق ليسانس & \\
\hline$\% \circ / V$ & r & دكترى & \\
\hline$\% \circ / \mathbb{f}$ & 1 & - & بى ياسخ \\
\hline$\% 100$ & rAD & & كل افراد \\
\hline
\end{tabular}

\section{تحليل دادهها}

در اين يزوهش براى بررسى قدرت نشــانخرهاى مربوط به هريك از صفات مكنون، از تحليــل عامل تأييدي جههارعاملــي مرتبه دو (روش حداكثر بزر گنمايي بوت اســتراب' در Amos) و از نرم افزار 18 Amos استفاده شد. براى ايجاد متغيرهاى نهفته، ضرورى است نشــانگرهاى جندكانه از هر متغير وجود داشته باشد. معمولأ از زيرمقياسهاى سنجهها

$$
\text { بهعنوان نشانغر هاى جداكانه معرف سازه نهفته استفاده مىشود. }
$$

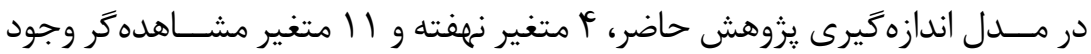
داشــتـند. متغير نهفتـُ شـــاخت كه بهعنوان يكى از متغيرهاى نهفته مرتبه يك در نظر گرفته شد، داراى ץ زير مقياس آموزش توانمندى در بازدارى و يرهيز، يرورش عقلانى و آموزش شناخت فضائل بود، متغير نهفتـ باور نيز كه بهعنوان ديخر متغير نهفتـُ مرتبه يك در نظر گرفته شد، داراى أزير مقياس بينش نسبت به خويشتن، بينش نسبت به خدا، بينش نسبت به سلامت محيط زندگى و انخيزش جهت تحكيم ييوندهاى اجتماعى بود و متغير نهفتهُ رفتار نيز كه بهعنوان يكى ديخر از متغيرهاى نهفته مرتبه يك در نظر گرفته شد، داراى F زير مقياس مشاركت اجتماعى، آكاهى و هوشيارى، تصميهم گيرى اخلاقى و انجام وظيفه و عمل به تكليف بود (شكل r). 


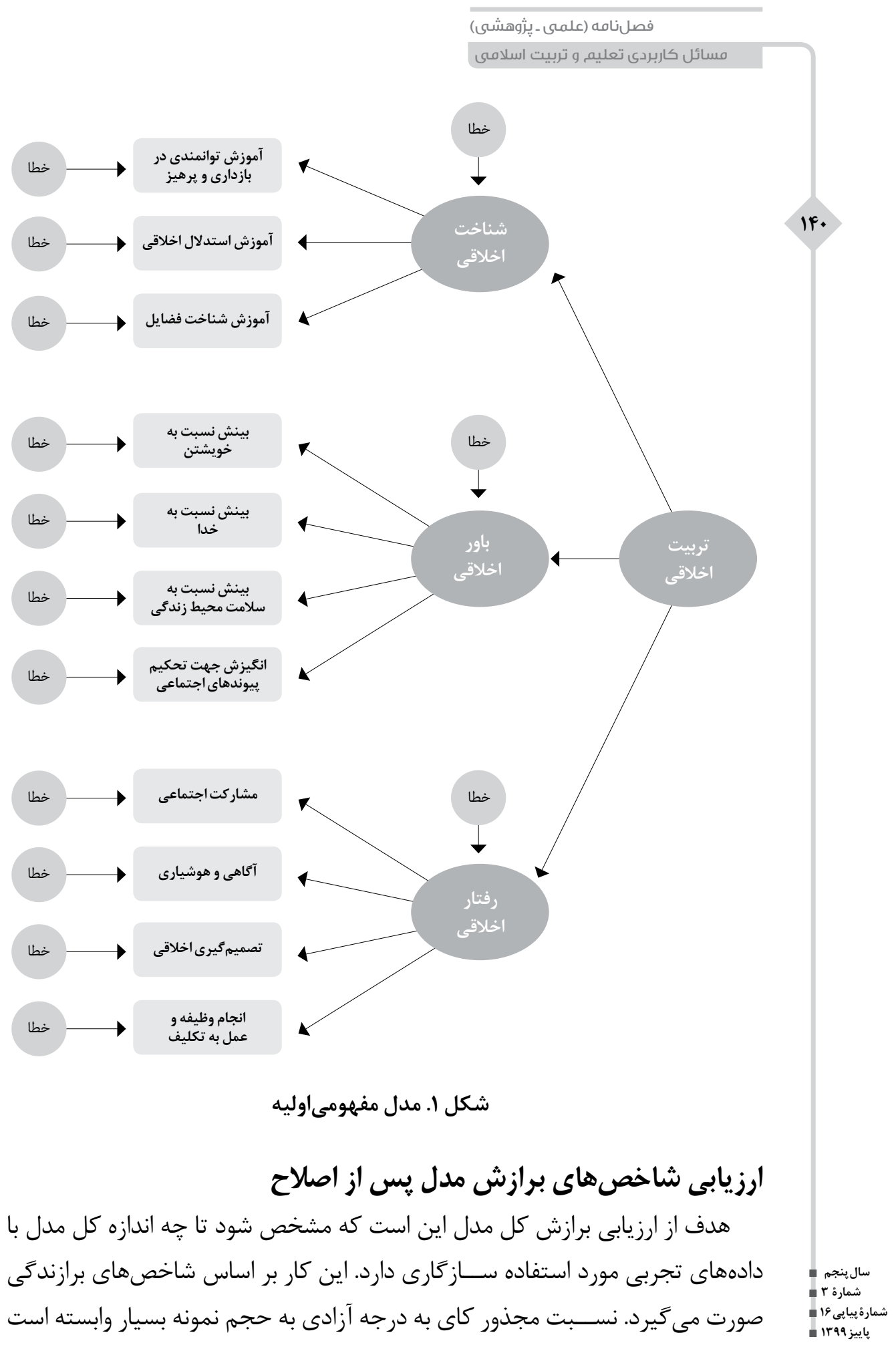




\section{$\mid T V-1 \Delta F$}

و نمونـــه بزرَّ كميت خــى دو را بيش از آنجهه بتوان آن را به غلط بودن مدل نســبت داد، افزايش مى دهد. ايدهآل آن اســت كه مقدار خحى دو داراى سطح معنادارى بيشتر از

ه ه/ه باشــد يا مقدار خى دو تقســيمم بر درجه آزادى بين ا تا س باشد (هومن، سوسا). با توجه به مقدار ززارش شــده براى اين مقدار در جــدول أل، مقدار خى دو معنادار بود ولى از طرفى مقدار خى دو تقســيم بر درجه آزادى سVD/ بود كه نشان دهنده برازش مناســب مدل مىباشــد، ولى با توجه به اينكه حجم نمونؤ اين تحقيق بيش از ه مب نفر است، از شاخصهاى ديگر براى مناسب بودن برازش مدل استفاده شد. معيارهاى خوبى

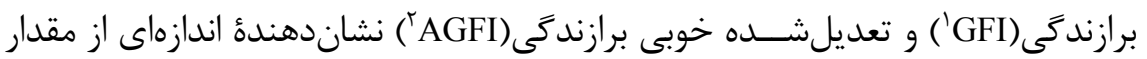
نسبى واريانس ها و كوواريانسهاست كه توسط مدل تبيين مىشود. هر دوى اين معيارها بيــن صفر تا يــــ متغيرند كه هر جهه به عدد يك نزديكتر باشـــند، نيكويـى برازش مدل با دادههاى مشـــاهده شده بيشــتر اسـتـ. مقادير GFI و AGFI در مدل نهايى بالاتر از

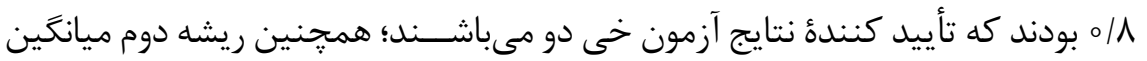
مربعــات باقيمانده (RMR) هر جه به صفر نزديكتر باشـــ، مدل مذكور برازش بهـترى

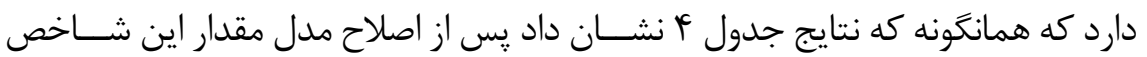

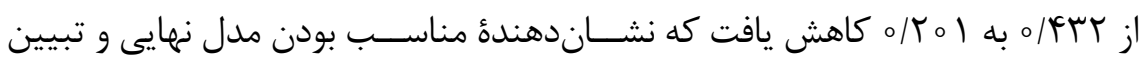
مناسب كوواريانسها مىباشد؛ براى بررسى اينكه يك مدل بهخصوص در مقايسه با ساير مدل هاى ممكن از نظر تبيين مجموعهاى از دادهاى مشاهده شده تا جه حد خوب عمل

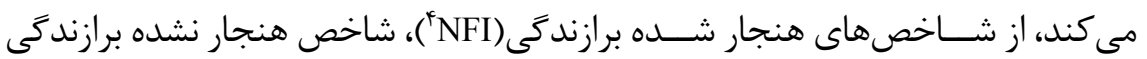

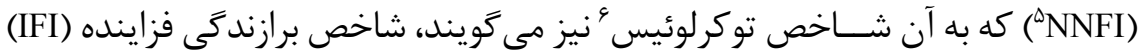
و شاخص برازندگى تطبيقى(CFI') استفاده مىشود. مقادير بالاى 9/ه اين شاخصها نيز حاكى از برازش بســيار مناسب مدل نهايى است (Gefen , Strub, \& Boudrean, 2000). در نهايت براى بررسى اينكه مدل موردنظر جُگونه برازندگى و صرفهجويى را با هم تركيب

1. Goodness of Fit Index(GFI)

2. Adjusted Goodness of Fit Index (AGFI)

3. Root Mean Residual RMR)

4. Normed Fit Index (NFI) 
مى كند، از شاخص بسيار توانمند ريشه دوم ميانگين مربعات خطاى برآورد (RMSEA') اســـفاده شد، اين شاخص براى مدلهاى خوب هـ/ه و كمتر است، مدلى كه در آن اين شــاخص //ه يا بيشتر باشد برازش ضعيفى دارد (هومن، سوس|)، مقدار اين شاخص نيز براى مدل اصلاح شدهُ نهايى اله ه/ه بود ؛ بنابراين همخى اين شاخصها نشان دادند كه مدل مورد نظر در اين تحقيق يس از اصلاح (شكل r)، برازندگى بسيار مناسبى با دادهها ييدا كرده است. در صورتى كه اكثر اين شاخصها، قبل از اصلاح مدل در سطح غيرقابل قبولى قرار داشتند (جدول ()).

جدول f. ضر ايب شاخصهاى برازندكى در مدل ييشنهادى و مدل اصلاح شده

\begin{tabular}{|c|c|c|c|c|}
\hline ت تفسير & دامنه قابلقبول & مقدار & شاخصهاى برازش & 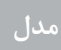 \\
\hline برازش نامطلوب & از كمتر از r تا حداكثر هـ & $N / r \Delta q=r \Delta 1 / 09 \Delta \div F r$ & تقسيم X بر درجه آزادى & \\
\hline برازش نامطلوب & P بيشتر از ه ه P & $(P=\circ / 0 \circ \circ) r \Delta / / \circ 9 \Delta$ & $\chi^{r}$ & \\
\hline برازش مطلوب & بيشتر از ^/ه & $\circ|\wedge|$ & GFI & \\
\hline برازش نامطلوب & بيشتر از \/ه & $\circ / \mathrm{VI}$ & AGFI & \\
\hline برازش نامطلوب & نزديك به صفر & o/frt & RMR & 3 \\
\hline برازش نامطلوب & بيشتر از 9/ه & o|AF| & NFI & $\frac{2}{2}$ \\
\hline برازش نامطلوب & بيشتر از ه 9/ه & O/AIT & TLI & \\
\hline برازش نامطلوب & بيشتر از 9/ه & $\circ / \Lambda \Delta V$ & IFI & \\
\hline برازش نامطلوب & بيشتر از 9/ه & -/ADG & CFI & \\
\hline برازش نامطلوب & كمتر از هـ/ & $0 \mid 191$ & RMSEA & \\
\hline
\end{tabular}

1. Root Mean Square Error of Approximation(RMSEA) 


\section{$I T V-I Q F$}

جدول Fiامه (ادامه

\begin{tabular}{|c|c|c|c|c|}
\hline تفسير & دامنه قابلقبول & مقدار & شاخص هاى برازش & مدل \\
\hline برازش كاملاً مطلوب & از كمتر از r تا حداكثر ه & $I / V \Delta r=r \Delta / \Delta V \div r G$ & تقسيم لُ بر درجه آزادى & \\
\hline برازش نامطلوب & Pيشتر از هـ/ P & $(\mathrm{P}=0 / 01) \mathrm{F} \Delta / \Delta V$ & $\chi^{r}$ & \\
\hline برازش كاملاً مطلوب & بيشتر از \/ه & o/9VT & GFI & \\
\hline برازش كاملاً مطلوب & بيشتر از ^|ه & - & AGFI & \\
\hline برازش مطلوب & نزديك به صفر & $0 / Y \circ 1$ & RMR & 3 \\
\hline برازش كاملاً مطلوب & بيشتر از 9/ه & $\circ / 9 \vee 9$ & NFI & 3 \\
\hline برازش كاملاً مطلوب & بيشتر از ه 9/ه & $0 / 911$ & TLI & \\
\hline برازش كاملاً مطلوب & بيشتر از 9/ه & $0 / 991$ & IFI & \\
\hline برازش كاملاً مطلوب & بيشتر از 9/ه & $0 / 991$ & CFI & \\
\hline برازش كاملاً مطلوب & كمتر از هـ/ & $\circ / \circ \Delta 1$ & RMSEA & \\
\hline
\end{tabular}

\section{ارزيابى بخش اندازهَيرى مدل اصلاح شده}

آزمون مدل اندازهزيرى جهت ارزيابى اين اسـت كه متغيرهاى مورد اندازهخيرى تا جه حد به خوبى ســازههاى نهفته را بازنمايى مى كنــــــ. در ارزيابى بخش اندازهذيرى مدل بايد به بررسى ميزان و سطح معنادارى مسيرهاى بين هر يك از متغيرهاى ينهان با شــاخصهاى مربوط به آنها يرداخت كه براى آزمون معنــادارى تأثير گذارى آنها، از

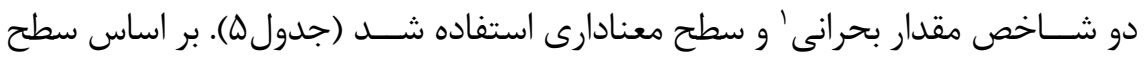

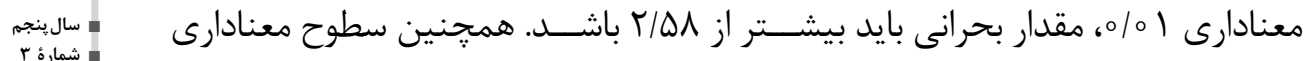


كوجى تر از ه ه/ه يا ا ه/ه حاكى از وجود تفاوت معنادار ضرايب تأثير (وزن رَرســيون) با مقدار صفر در ســـح اطمينان هو٪\% يا 99٪ است. بنابر اين يافتههاى جدول ه با توجه به اين دو شــاخص، به خوبى نشـــان داد كه تمامىمســـيرهاى بين متغيرهاى ينـهان و نشانگرهاى هر يك در يزوهش حاضر معنادار بود كه نشان دهنده معنادارى بارهاى عاملي مدل اندازهخيرى اين تحقيق بودند. همجنـين نتايج جدول ه نشــان داد با توجه به ضرايب اســـاندارد متغيرهاى ينهان مرتبه اول بر روى نشــانگرهاى خود، اثر متغير نهفتته شناخت بر نشانخر آموزش شناخت

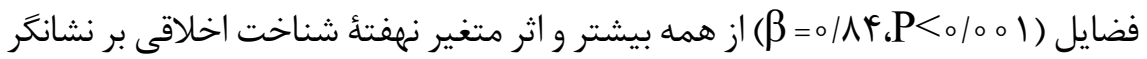

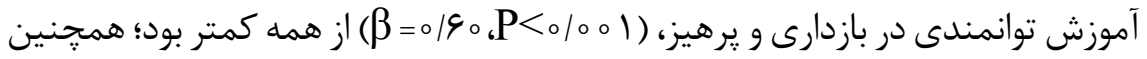
اثر متغير نهفتُ باور بر نشانگر بينش نسبت به خدا ( و اثر متغير نهفتهٔ باور اخلاقى بر نشانگر بينش نسبت به خويشتن (

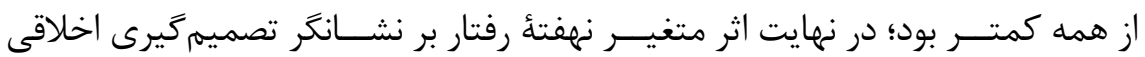

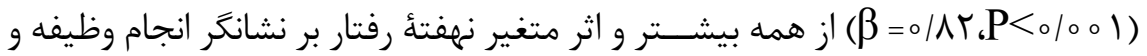

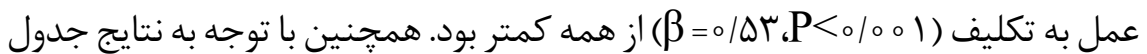
ه، צس درصد از واريانس نشــانگر (آموزش توانمندى در بازدارى و يرهيز"، سه درصد از

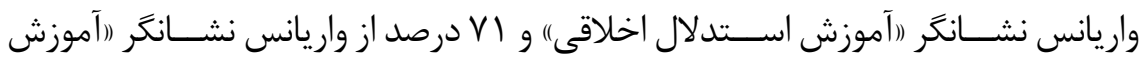
شناخت فضايل)" توسط متتير رينهان شناخت قابل تبيين بود. بنابراين شناخت بين همأ

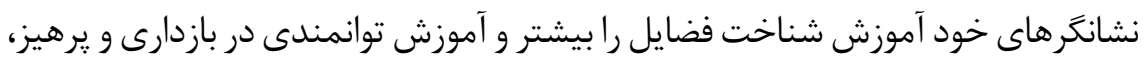
را كمتر از همه تبيين كرده اســت. از طرفى له درصد از واريانس نشانگر (بينش نسبت به خويشتن)، هو درصد از واريانس نشانگر (بينش نسبت به خدا)، وه درصد از واريانس إنس نشانگر (بينش نسبت به سلامت محيط زندگى") و V9 درصد از واريانس نشانگر (انگيزش جهت تحكيم پييوندهاى اجتماعى" توسط متغير ينهان باور قابل تبيين بود. بنابراين باور بين همهٔ نشــانكرهاى خود بينش نســبت به خدا را بيشتر و بينش نسبت به خويشتن را كمتر از همه تبيين كرده اســت. در نهايت هل أ درصد از واريانس نشــانكر (امشاركت

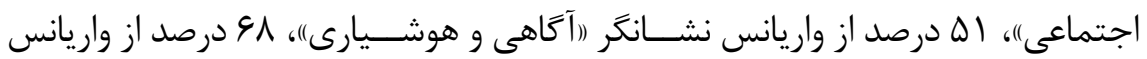

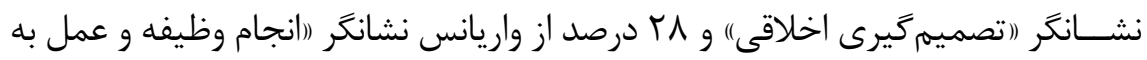
تكليفه توســط متغير ينهان رفتار قابل تبيين بود. بنابراين رفتار بين همةٔ نشانخرهاى 


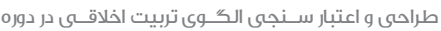
ابتدايىىنظام آموزشى جمهورى اسلامى إيران

ITV-IQF

خود تصميم كيرى اخلاقى را بيشتر و انجام وظيفه و عمل به تكليف را كمتر از همه تبيين كرده است.

جدول ه. اثرات مستقيم متغيرهاى نهفته مرتبه اول بر نشانغرها در مدل نهاييى

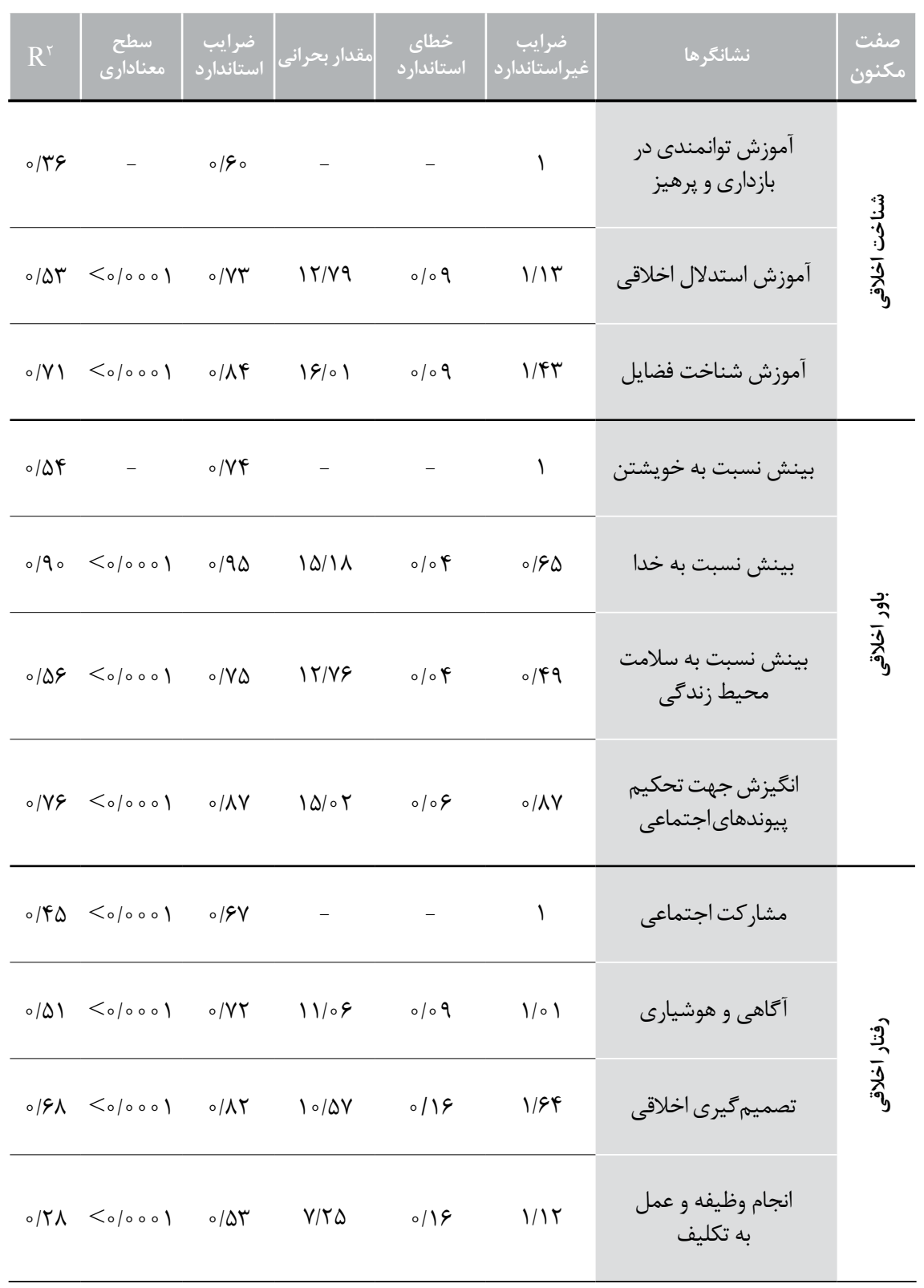




\section{ارزيابى بخش ساختارى مدل اصلاح شده}

در ارزيابى بخش ســاختارى، ارتباط بين متغيرهاى ينهان تحقيق مورد بررسى قرار مى گيـــد. اثر متغير ينهان بيرونى بر متغير ينهان درونى بهعنوان ضريب كاما شـــناخته

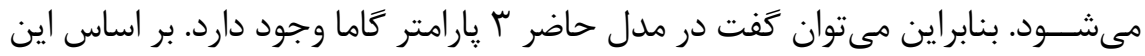

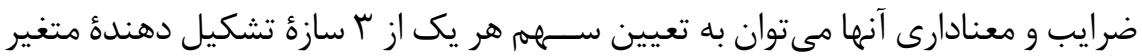

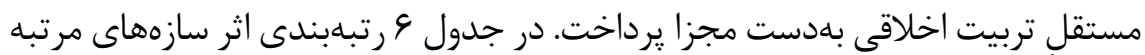

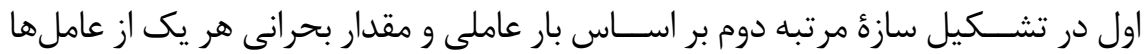

جدول 9. رتبه بندى اثر سازههاى مرتبه اول در تشكيل سازه مر تبه دوم بر اساس بار عاملى در مدل نهائ اوليى

\begin{tabular}{|c|c|c|c|c|c|c|c|}
\hline $\mathbf{R}^{r}$ & معنادارى & مقراند & استاندارد & ضرايب استارد & غير استاندارد & مترتبه اول و دونهان & رتبه \\
\hline ०/99 & $\circ / 000$ & IF/Tr &.$/ 14$ & $1 / 94$ &.$/ 91$ & تربيت اخلاقى بر باور & 1 \\
\hline ०/Ar & - & - & - & 1 &.$/ 91$ & تربيت اخلاقى بر شناخت & $r$ \\
\hline $0 / 99$ & $0 / 000$ & $10 / 09$ & $\circ / 09$ &.$/ 91$ & $\circ|\Lambda|$ & تربيت اخلاقى بر رفتار & $r$ \\
\hline
\end{tabular}

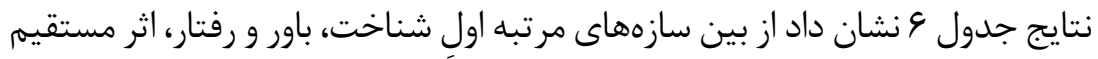

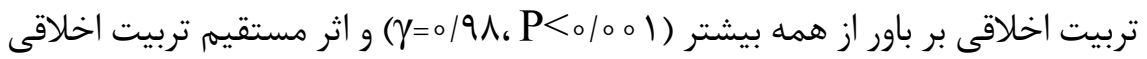

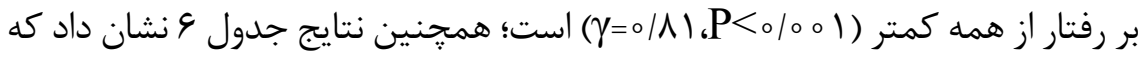

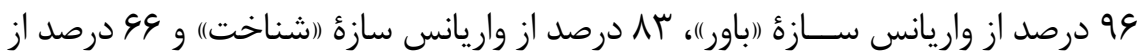

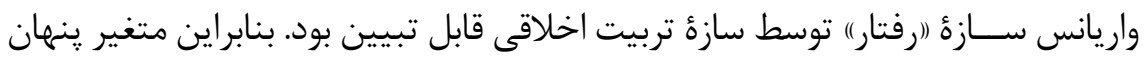

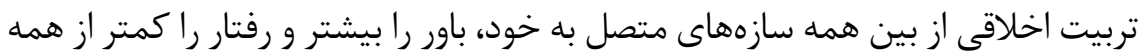
تبيين كرده است. 


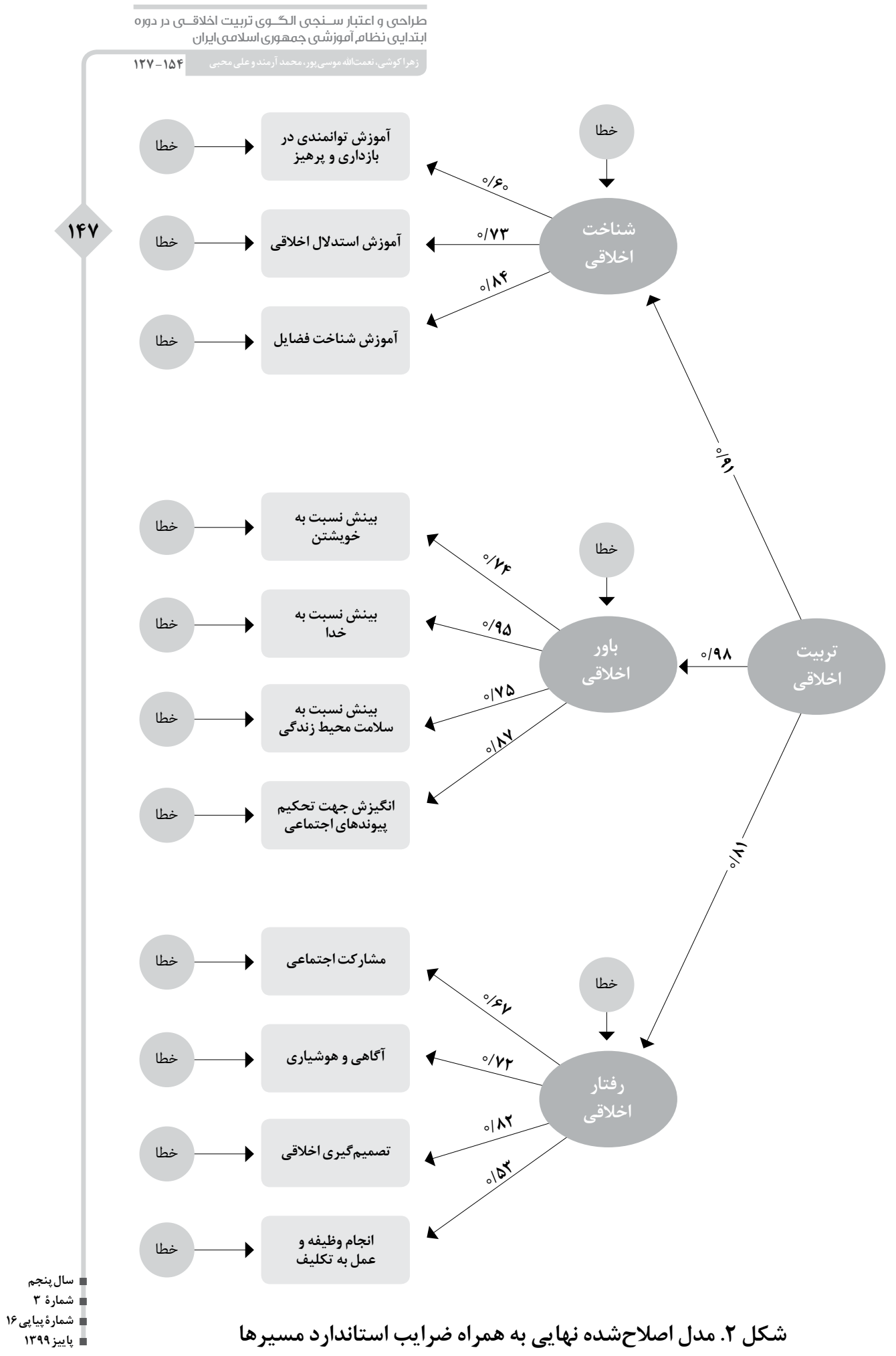




\section{بحث و نتيجه كَيرى}

در عصــر كنونى، معضلات و بحرانهاى متعدد و متنوعى گريبان گير افراد و جامعه كشته است. در ارتباط با اين هالشها، تربيت اخلاقى امر بسيار مهمىمىباشد. در كشور ما اكثر يزوهشها در حوزه تربيت اخلاقى با تأكيد بر مبانى فلسفى و رويكردهاى فردى و بدون توجه به تربيت اخلاقى با رويكرد اجتماعى تدوين شــدهاند (قاســمى، وهـ ا). رويكردهـــاى فردى به تربيت اخلاقى نمى توانند به خوبى از عهده اهداف تربيت اخلاقى بـى در عصــر كنونى برآيند. زيرا ارتقاء اخلاقى انســان در حين زندكَىى اجتماعى وى رخ مى دهد. بنابراين، اخلاق اجتماعى جنبهاى عملى دارد و نوعى سَـــبك زيستن مى بـاشد. نظام آموزشــى بايد به شكل گيرى تربيت اخلاقى در دانشآموزان اهتمام ورزد تا اين امر به نحو احســن صورت گيرد. در واقع نظام تعليمهوتربيت اســت كه مىتواند ارائهدهنده راهكارهايى براى جالشهاى فعلى دنياى امروز باشد. با توجه به مطالب مذكور، يزوهش

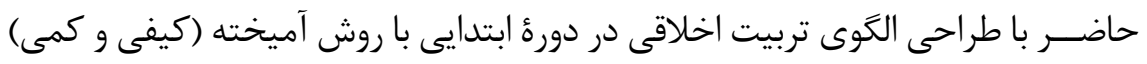
انجام شــد. از اين رو، ابتدا با كمك مطالعات اسنادى و كتابخانهاى و تحليل محتوا، 11

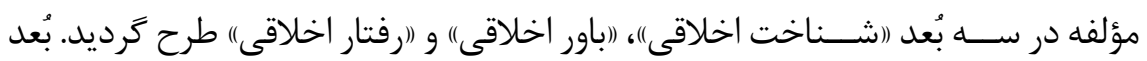
((شـــناخت اخلاقى)" مشتمل است بر مؤلفههاى (آموزش توانمندى در بازدارى و يرهيز)،

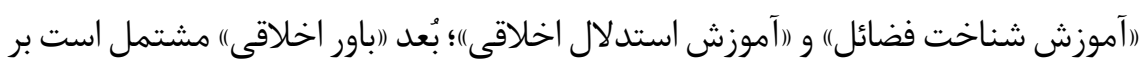
مؤلفههاى ((بينش نسبت به خويشتن)، ((بينش نسبت به خدا)، ((بينش نسبت به سلامت

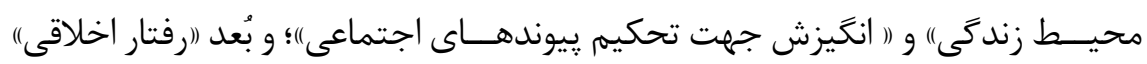

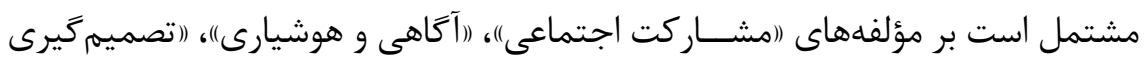
اخلاقى)، و (انجام وظيفه و عمل به تكليف). اين ابعاد بر اساس شاخصهاى كمى آزمون

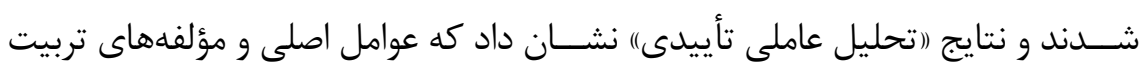
اخلاقي موجود در الخو عوامل مناسبى هستند، زيرا با توجه به شاخصهاى بهدست آمده،

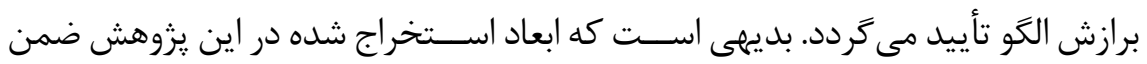

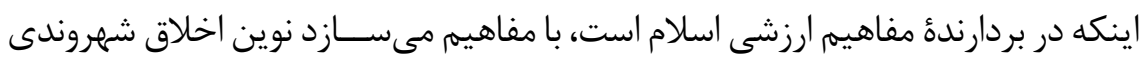

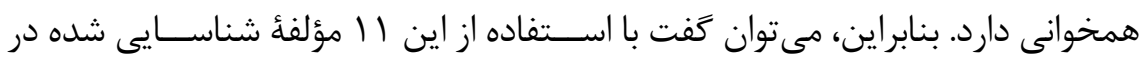
تربيت اخلاقى مدارس، شــهروندانى اخلاقمدار يرورش داد. اين نتايج با نتايج انصارى و موسى

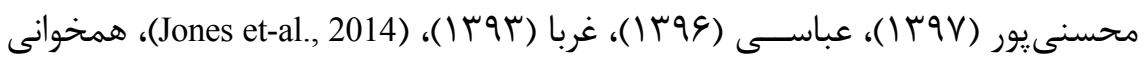




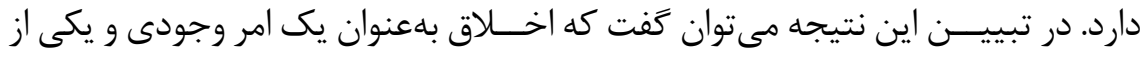

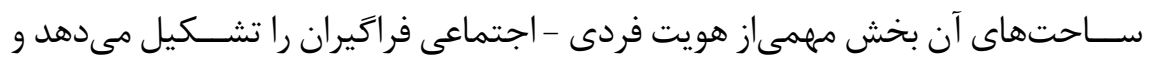

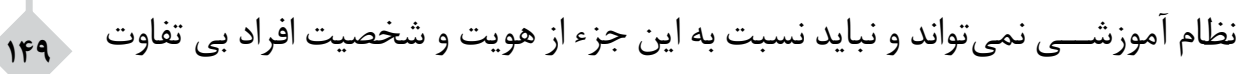

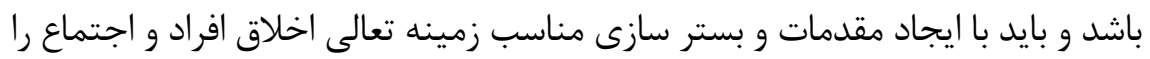

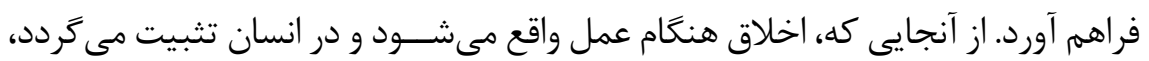

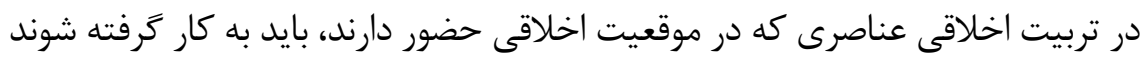

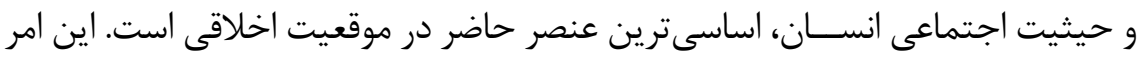

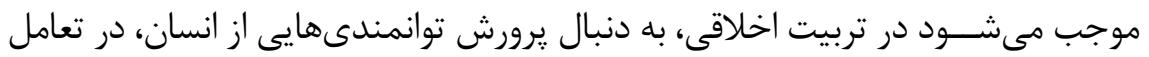

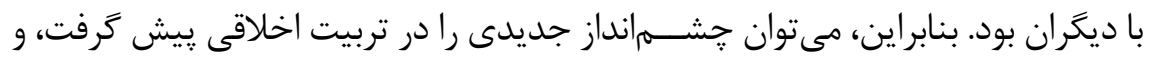

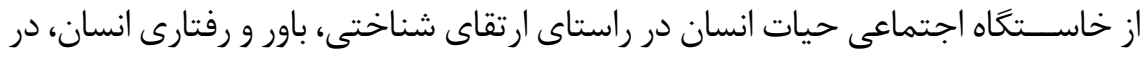

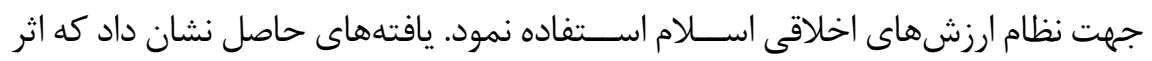

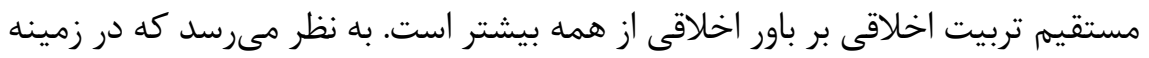

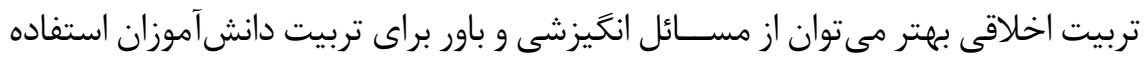

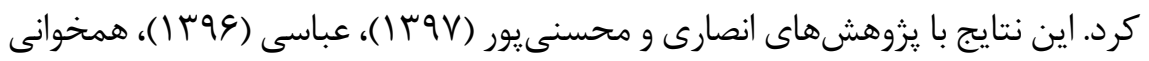

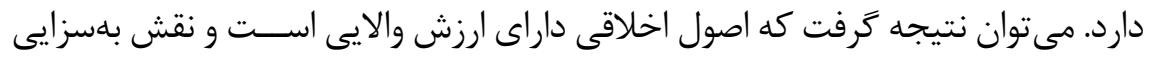

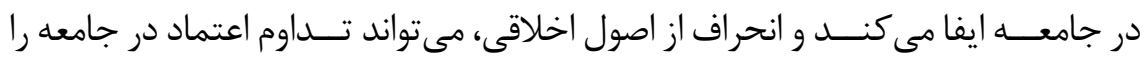

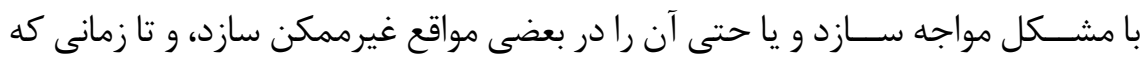

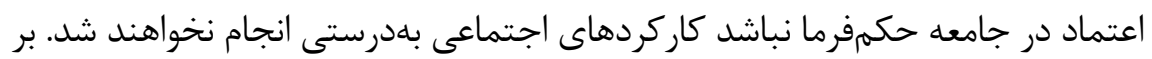

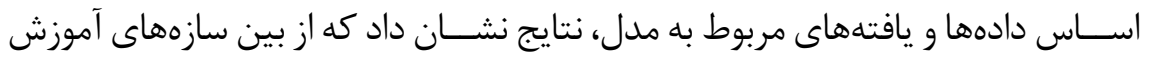

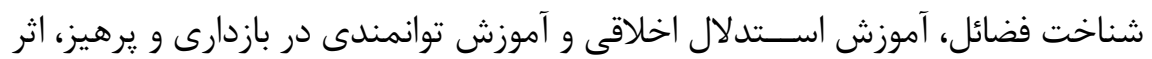

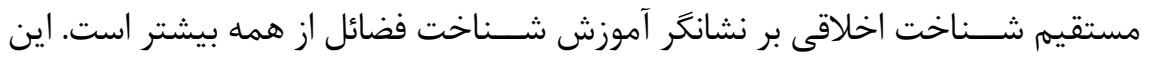

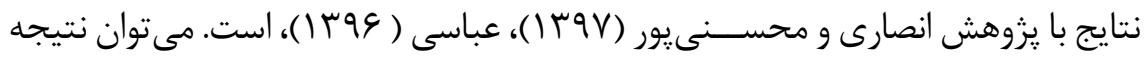

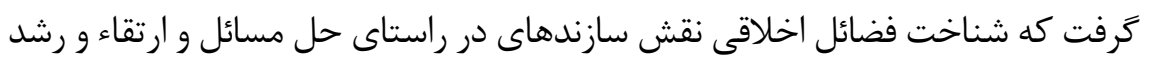

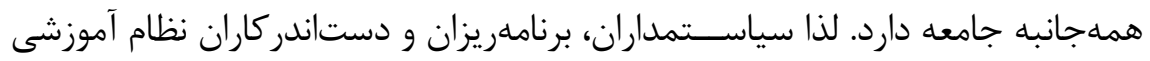

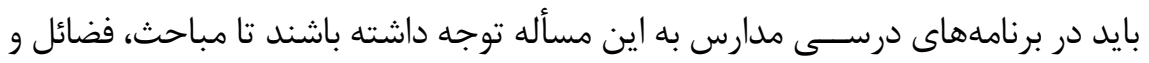

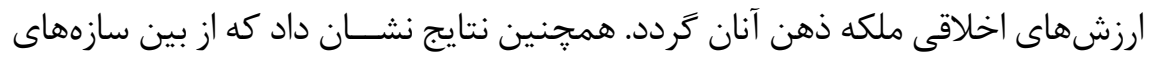

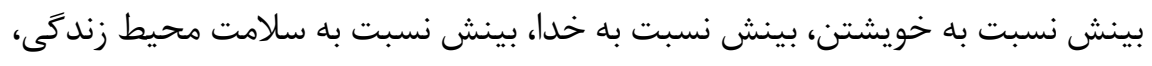


و انخيزش جهت تحكيه ييوندهاى اجتماعى، اثر مســتقيهم باور اخلاقى بر نشانگر بينش نسبت به خدا از همه بيشتر است. اين نتايج با يزوهش عباسى (9 (1) )، همسو مىباشد. از آنجايى كه ايمان به خدا در تمامى اخلاق گَنجانده شده و اخلاق هم جيزى جز رسيدن به قربالى الله نيست، بر همين اساس مىتوان گفت بين تربيت اخلاقى و دين درهم تنيدگى وجود دارد، و بينش نسبت به خدا هستى مستلزم استمداد و استعانت از خدا و تواضع و فروتنى در مقابل خالق هســتى مىباشد. لذا در طراحى الخوى تربيت اخلاقى مىبايست

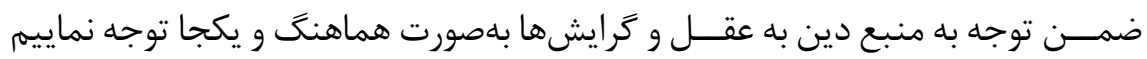
تا دانشآموزان به قربالى الله دسـت يابند. همجنين نتايج نشان داد كه از بين سازههاى آتاهى و هوشيارى، تصميم گيرى اخلاقى، اهميت شرايط اخلاقى، و انجام وظيفه و عمل به تكليف، اثر مستقيم رفتار اخلاقى بر نشانگر تصميمىيرى اخلاقى از همه بيشتر است. اين نتايج با يزوهش عباسـى و ديخران (99 (1)، همسو است. هنخامى كه بستر و شرايط تربيت اخلاقى در مدارس فراهم شود و به ابعاد و ارزشهاى تصميم گيرى اخلاقى از جمله ادراى اخلاقى، قضاوت اخلاقى، تمايل و كرايش اخلاقى، و اهميت شـــرايط اخلاقى كه اشاره به فضا و محيطى دارد كه ارزشهاى اخلاقى در آن زمينهساز تصميهميرى اخلاقى مىشود توجه گردد، مى توان شاهد افزايش تربيت اخلاقى در ميان دانشآموزان بود. بر اساس يافتههاى مطالعه حاضر، يكى از مهممترين ثيامدهاى الكوى تربيت اخلاقى

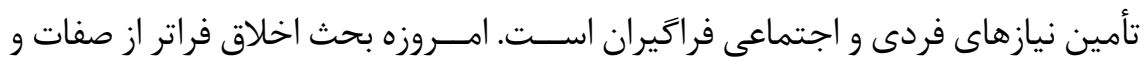
ملكات بوده و به دامنهُ وســيع كارهاى ارزشى انســـان ربط داده شده است. عصر حاضر، عصر بحرانها و جالشهاى زياد و بنيانافكن است و اگر بشر بخواهد تعادل روانى داشته باشد بايد به اخلاق و تربيت اخلاقى روى آورد. نآَاهى دانشآموزان از مؤلفههاى تربيت اخلاقى مى تواند آسيبهاى جبران نايذيرى را همجون، بىمسئوليتى، بى توجهى به حقوق ديخــــران، دورى از حس نوع دوســـتى، عدم توجه به حقوق حيوانــات، يِيش داورىهاى غيرمنطقى، ترجيح احساس بر عقل در حوزه تصميمات اخلاقى و فاصله گرفتن از فطرت ياك انســانى و عدم تلاش بـــراى :رورش همهجانبه آن در رســيدن به كمال را متوجه نسل آينده نمايد. تربيت اخلاقى سبب شكل گيرى رفتار اخلاقى مى گردد. رفتار اخلاقى رفتار خاصى است كه در يك محيط خاص، از طرف عموم بهعنوان رفتار خوب و صحيح و در مقابل رفتار بد و نادرســت قرار دارد. اين رفتارها شــامل صداقت، تعهد، مهربانى، 


\section{$1 T V-1 Q F$}

دلسوزى، تواضع، شجاعت، فروتنى مىباشد كه مبين مسئوليتهاى اخلاقى است. وقتى از اخلاقى بودن فردى صحبت مىشــود در واقع مســــوليتيذير بودن آن فرد به ذهن

متبادر مىشــود. بنابراين مىتوان جشمهانداز نوينى را در تربيت اخلاقى بيش گرفت. در اين جُشـــمانداز نوين به تربيت اخلاقى، نقش انسان در اجتماع برجسته مىشود. آموزش

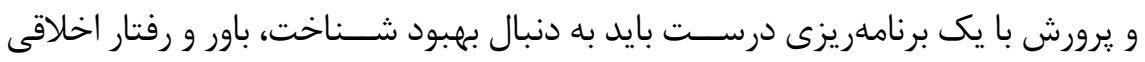

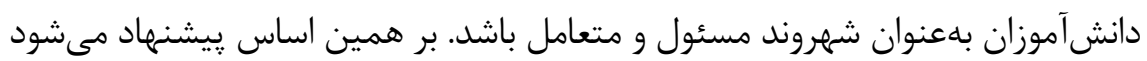
كه در مدارس فرصتهاى تعامل و ارتباط غير رســمىبين دانشآموزان و معلمان فراهم گرددد. همجنين لازم اســت منابع و كتب درسى بتوانند ارزشهاو باورهاى اخلاقى رادر دانشآموزان نهادينه كنند تا اين ارزشهاو باورها در رفتار آنان نمود يابند. بايد از طريق آموزش خانواده، والدين را ييرامون ارزشهاى اخلاقى آكاه نمود تا آنها بتوانند با توجه به نقش الخويى خود تأثير حذارى بيشـــتى در تربيت اخلاقى فرزندان خود داشته باشند. از سويى ديخر، لازم است كه صدا و سيما جهت فرهنگ سازى استفاده مناسب از رسانهها و شبكه هاى مجازى و هدايت دانشآموزان بهسوى ارزشهاى اخلاقى مطلوب برنامههايى را تدارك بيند. در نهايت هر تحقيقى با محدوديت مواجهه است كه اين تحقيق نيز از اين امر مستثنى نيست. محدوديت اصلى اين :زثوهش كدبندىها و شناسايى عوامل فرعى و اصلى در بخش كيفى بود. يكى ديخر از اين محدوديتها عدم تمايل پاســـخَّويى برخى

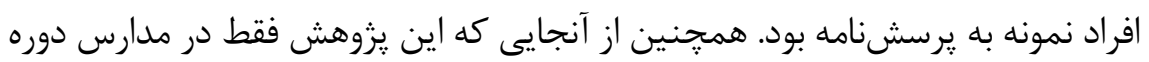

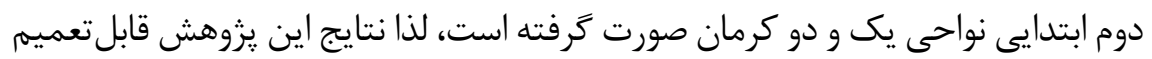
به ساير مقاطع تحصيلى و شهرهاى ديخر نمىباشد.

\section{تشكّر و قدردانى}

اين مقاله بركرفته از رسالهُ دكترى تخصصى برنامهريزى درسى با عنوان اخناسايى و

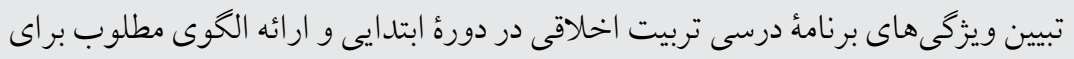

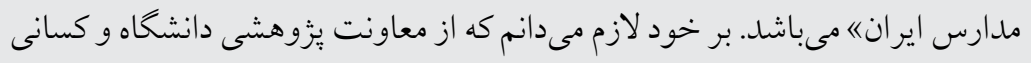
كه در جمع آورى اطلاعات اين يزوهش ما را يارى رسانيدهاند و به خاطر مشاورههاى 


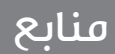

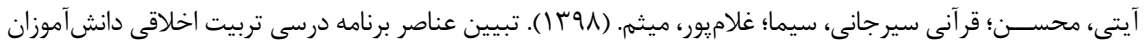

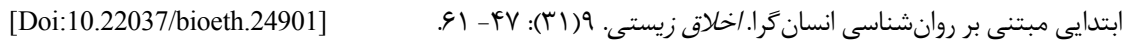

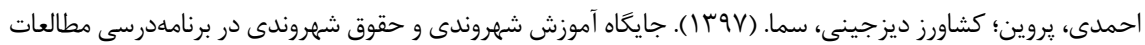

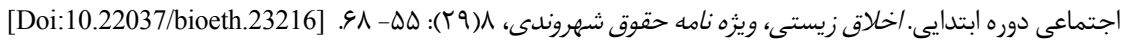

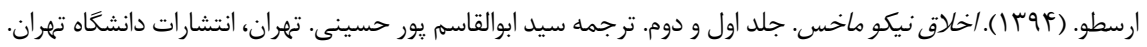

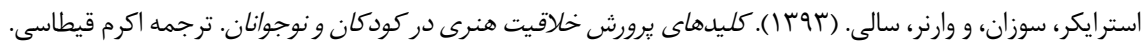
تهران: صابرين.

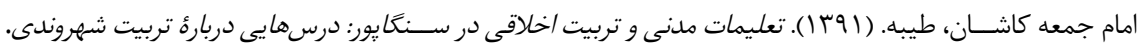
تهران: مدرسه.

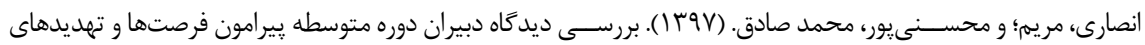

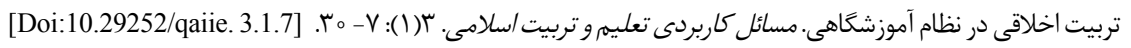

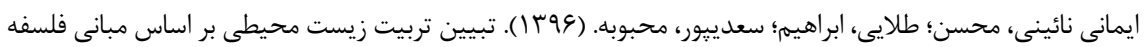

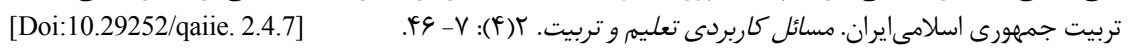

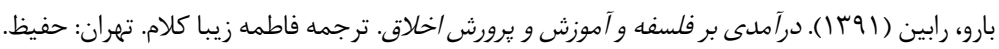

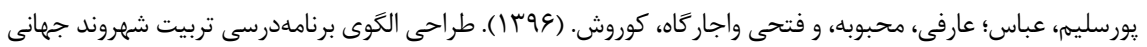

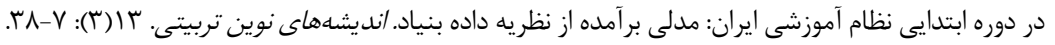
[Doi:10.22051/JONTOE.14097.1688]

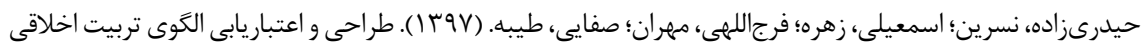

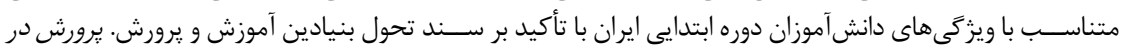

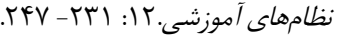

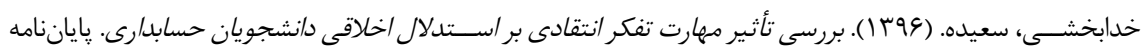
كارشناسى ارشد بوشهر.

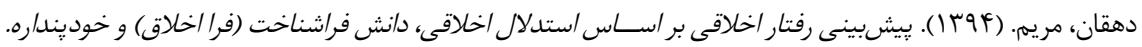
يايان نامه كارشناسى ارشد دانشخاه ياسوج.

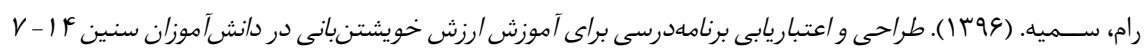

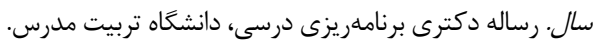

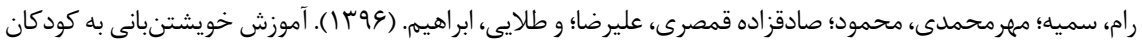

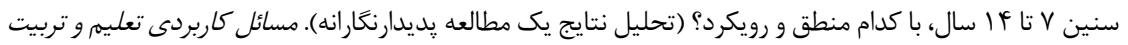
[Doi:10.29252/qaiie. 2.3.87]

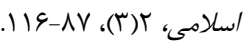

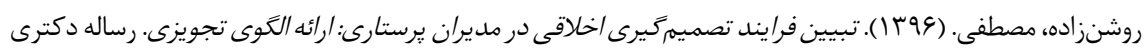
تخصصى، دانشكاه تربيت مدرس.

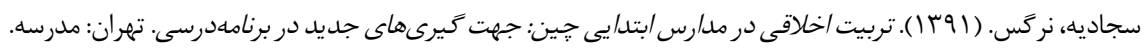

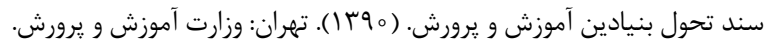

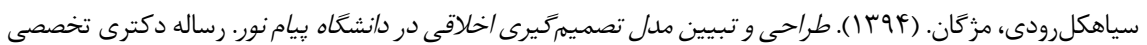

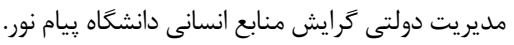

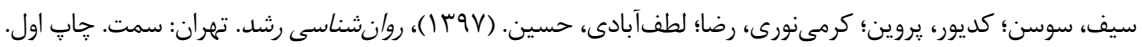

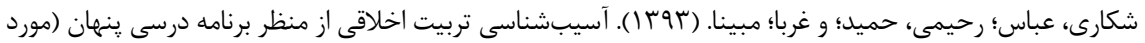

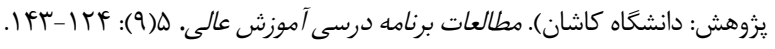




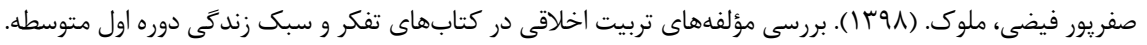

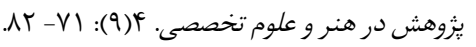

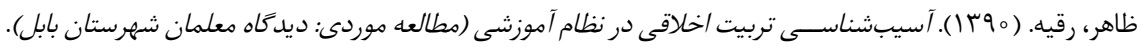
يايان امه كارشناسى ارشد دانشخاه مازندران.

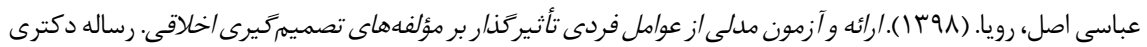
تخصصى روانشناسى تربيتى دانشكاه مازندران.

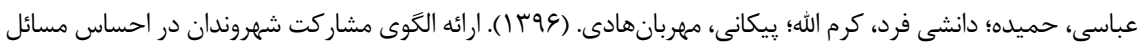

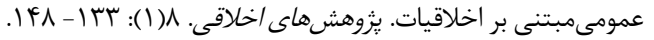

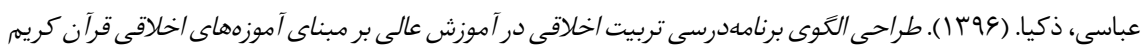

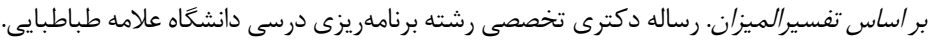

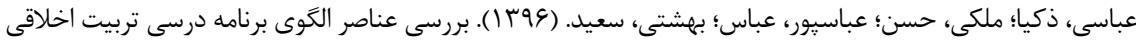

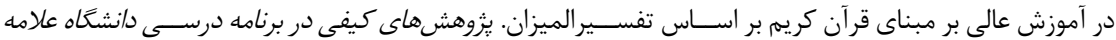
[Doi: 10.22054/QRIC.27922.188]

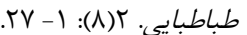

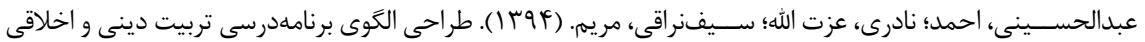

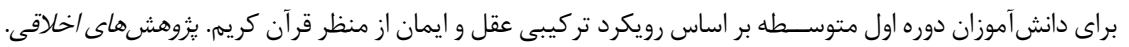
$.119-101:(Y) 9$

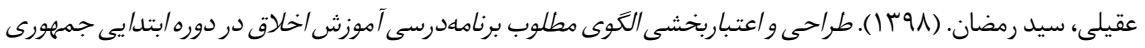

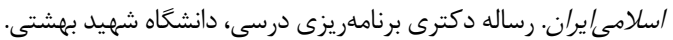

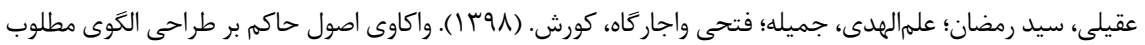

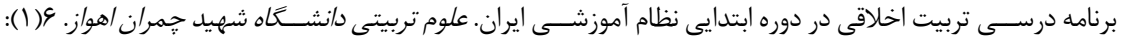
[Doi: 10.22055/EDUS.26634.2585] MF-IV

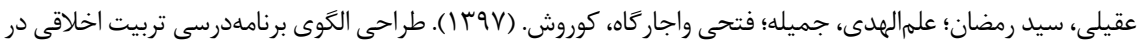

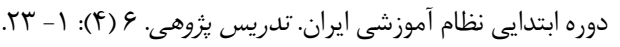

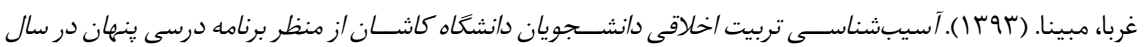

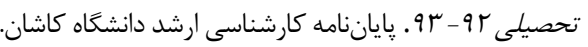

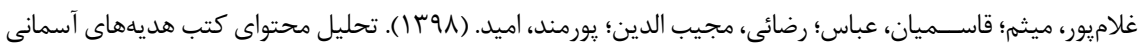

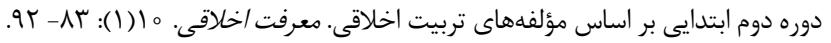

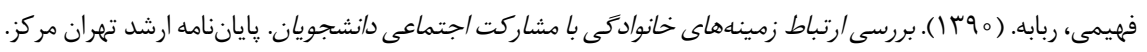

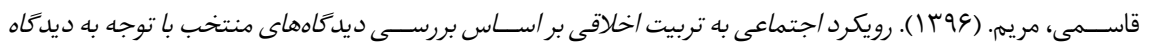
تفسيرى علامه طباطبايى. رساله دكترى دانشخاه تهران.

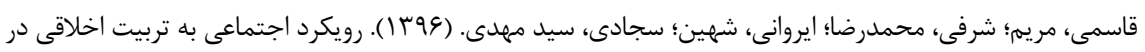

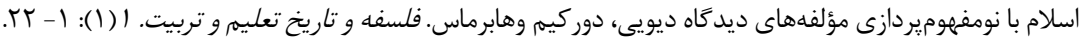

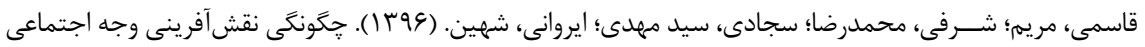

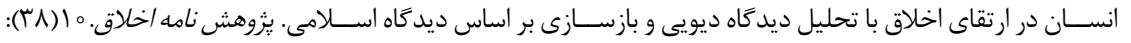

$.111-99$ قائدى، يحيى. (1) (1) (1). تربيت اخلاقى در خاين: دلالتهايى براى مدارس آمريكا. تهران: مدرسه.

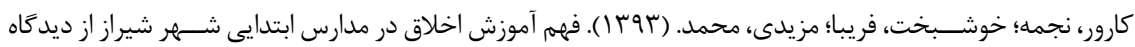
[Doi: 10.22099/JCR.3107]

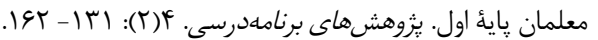

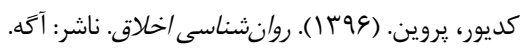




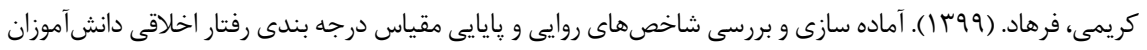

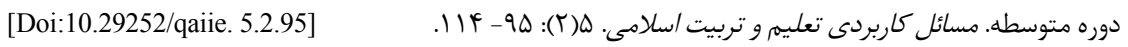

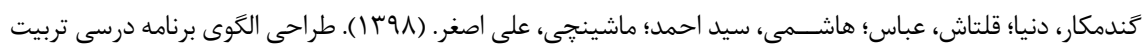

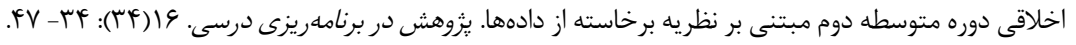

[Doi: 10.30486/JSRE.665142]

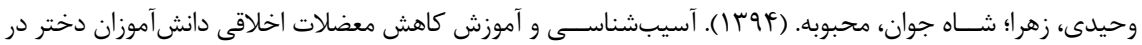

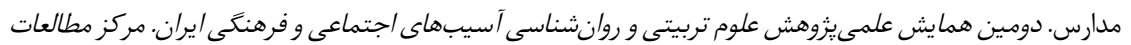

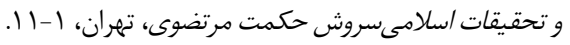

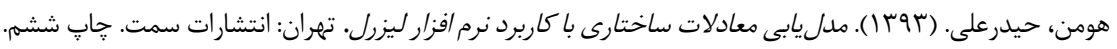

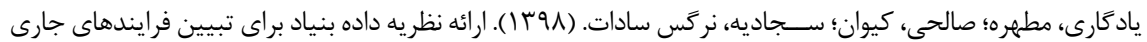

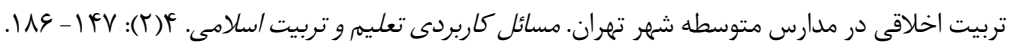

\section{REFERENCES}

[Doi:10.29252/qaiie. 4.2.147]

Berkowitz, M. W., \& Bier, M. C. (2015). What works in character Education: A research- driven guide for educators. Washangton, Dc: character Education.

Bischoff, K. (2016). The Civic Effects of schools: Theory and Empirics. Theory and Research in Education, 14(1), 91- 106. [Doi.org/10.1177/1477878515619794].

Bryan, H., \& Burstow, B. (2018). Understanding ethics in school based research. Professional Development in education, 44(1), 107- 119. [Doi.org/10.1080/19415257.1361464].

Bucciarelli, Monica, Laired, P. N. Johnson, (2008). The Psychology of Moral Reasoning, Judgment and Decision Making, 3(2), 121- 139.

Butcher, J. (2017). Citizenship, global citizenship and volunteer tourism: a critical analysis. Tourism Recreation Research, 42(2), 129- 138. [Doi.org/10.1080/02508281.1295172].

Gefen, D., Strub, D. and Boudrean, M. (2000); "Structural Equation Modeling and Regression: Guidelines for Research Practice"; Communication of AIs, Vol. 7, 1-78.

Giordmaina, J., \& Zammit, L. (2019). Shaping the identity of the new Maltese through ethics education in Maltese schools. Education sciences, 9(4), 253. [Doi.org/10.3390/educsci9040253].

Halsted, J. M., Taylor, M.J. (2000). Learning and teaching about values: A review of recent research. Journal of Education, 30(2), 169- 202. [Doi.org/10.1080/713657146].

Hudson, T.D., Diaz Pearson, A. (2018). Developing the moral self: college students' understanding of living a moral or ethical life. Journal of college and character, 19(3), 185- 200.

Jennifer, B. (2020). Fostering Moral Understanding, Moral Inquiry \& Moral Habits through philosophy in schools: A Deweying Analysis of Australia's Ethical understanding curriculum, Journal of curriculum studies, 51(1), 84-100. [Doi.org/10.1080./00220272.1650116].

Johansson, E., Brownlee, J., Charlotte- Moore, C., Boulton- Lewise, Walker, S. \& Ailwood, J. (2011). Practices for teaching moral values in the early years: a call for A pedagogy of participation. Education, Citizenship and Social Justice, 6 (2), 109- 124.[ Doi.org/10.1177/1746197910397914].

Jones, J.N., Warnaar, B.L., Bench, J.H., \& Stroup, J. (2014). Promoting the development of moral identity behaviour, and commitment in a social action program. Journal of Peace Education, 11(2), 225- 245. [Doi.org/10.1080/17400201.898626].

Kristjánsson, K. (2016). Aristotelian Character Education. London and New York: Routledge.

Sandeep. K. (2015). Moral values education. IOSR Journal of Humanities and Social Science (IOSR-JHSS), 20(3), 21-26. 